\title{
Delayed and Denied: Toward an Effective ERISA Remedy for Improper Processing of Healthcare Claims
}

\author{
Katherine T. Vukadin
}

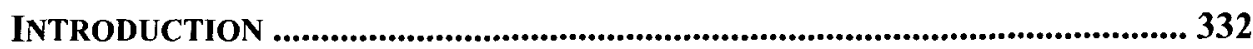

I. The Claims Processing Problem and ERISA......................................... 336

A. The Problem: Why Claims Regulations Matter............................. 337

B. ERISA'S PURPOSE AND BACKGROUND …………................................ 341

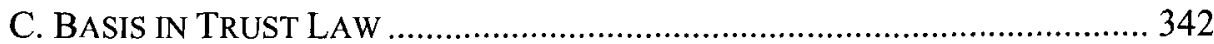

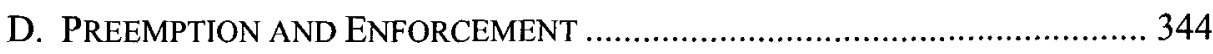

II. A REGULATORY FRAMEWORK WITH LITTLE INCENTIVE TO COMPLY . 346

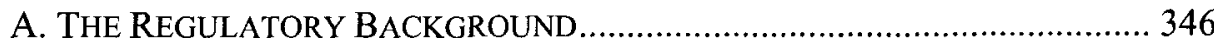

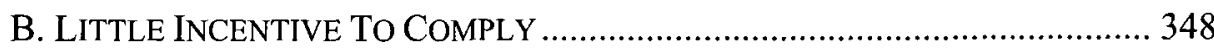

1. The "Substantial Compliance" Doctrine Sets the Bar Low .... 350

2. SubStantial NonCOMPLIANCE RESUlts in REMAND RATHER THAN A

SUBSTANTIVE REMEDY 351

3. The Most Flagrant Violations Do Not Result in a SUbSTantive REMEDY. 353

4. FREESTANDING Claims For BREACH OF FiduCIARY DUTY FAIL TO ADDRESS REGULATORY NON-COMPLIANCE 355

III. The PRESUMEd HARM APPROACH TO ENFORCEMENT OF ClaIMS PROCESSING REgULATIONS

A. RECOGNIZING THE HARM: ATTORNEY's FEES AS DETERRENT TO REGULATORY NON-COMPLIANCE 360

B. PRESUMING the HARM: A REgUlatory SOlUtion to Claims PROCESSING NON-COMPLIANCE.

1. Claims Processing Compliance Through a Presumed-Harm APPROACH AKIN TO THAT OF THE TRUTH IN LENDING LAWS 365

2. A SeParate PeAce: PieCEMEAL AND InCONSISTENT PRivate ReForm

THROUGH PROVIDER ClasS ACTIONS 371 


\section{INTRODUCTION}

ERISA is a comprehensive statute designed to promote the interests of employees and their beneficiaries in employee benefit plans.'

[E]very dollar provided in benefits is a dollar spent by . . . the employer; and every dollar saved ... is a dollar in [the employer's] pocket. ${ }^{2}$

The healthcare reform effort culminating in the Patient Protection and Affordable Care Act (PPACA) has focused, to date, on the plight of the uninsured and on barriers to insurance such as pre-existing condition exclusions. Reform efforts focus less often, however, on threats to healthcare benefits for people who do have health insurance. When insured individuals suffer a serious illness, does their insurance live up to its promise? One overlooked threat to the insured concerns administration of employer-sponsored health insurance plans. Specifically, participants' benefits are threatened by the lack of consequences when administrators of such plans improperly process claims for healthcare benefits by delaying the decision, failing to conduct a complete review, or simply denying the claim incorrectly.

For those covered by healthcare plans ("Participants"), a claim for benefits occurs each time the plan Participant seeks to access benefits under the plan. A Participant may seek benefits retrospectively or prospectively. ${ }^{3}$ In the case of a retrospective claim, a Participant seeks medical care and then files a claim with the plan, following the plan's prescribed process. ${ }^{4}$ The healthcare provider may file the claim on the Participant's behalf if the Participant has assigned benefits to the provider. ${ }^{5}$ The Participant then waits for the decision-maker ${ }^{6}$ to send the

* Assistant Professor of Law, Thurgood Marshall School of Law; J.D. 1999, The University of Texas School of Law; B.A. 1991, University of Houston. I am grateful to Danyahel Norris and Régine Sévère for their excellent research assistance. I thank Professors Cassandra L. Hill, Thomas Kleven, Rebecca K. Stewart, and Tobi Tabor for reviewing drafts of this article and offering their insightful comments. I thank Anne Traverse and Davor S. Vukadin for their insights and constant support. This research was made possible by a summer research grant generously provided by Thurgood Marshall School of Law.

1. Shaw v. Delta Air Lines, Inc., 463 U.S. 85, 90 (1983).

2. Metro. Life Ins. Co. v. Glenn, 554 U.S. 105, 112 (2008) (quoting Bruch v. Firestone Tire \& Rubber Co., 828 F.2d 134, 144 (3d Cir. 1987)).

3. Kanika Kapur, Carole Roan Gresenz \& David M. Studdert, Managing Care: Utilization Review in Action at Two Capitated Medical Groups, HeALTH AfF. 276 (June 18, 2003), http://content.healthaffairs.org/content/early/2003/06/18/hlthaff.w3.275.full.pdf.

4. How to File a Claim for Your Benefits, U.S. DEP'T OF LABOR, $\mathrm{http}: / /$ www.dol.gov/ebsa/publications/how_to_file_claim.html (last visited Feb. 16, 2011).

5. D. Brian Hufford, Managed Care Litigation: The Role of Providers, in HEAlTh CARE Litigation: What You Need To Know After Pegram 487, 501 (Practising Law Inst. ed., 2000) (" $[\mathrm{P}]$ hysicians frequently obtain assignments from their patients in order to permit them to 
required written notice of a decision, and if the claim is denied, the Participant decides whether to appeal. ${ }^{7}$ When the Participant seeks benefits prospectively, the Participant requests pre-authorization from the plan for the intended treatment. ${ }^{8}$ Prospective denials can also be appealed, although a Participant faced with a denial of pre-authorization must either go forward with the treatment or await a decision on appeal. ${ }^{9}$

Employer-sponsored healthcare plans are governed by the Employee Retirement Security Income Act of 1974 (ERISA). ${ }^{10}$ When Congress enacted ERISA, healthcare and claim denials were less problematic. At that time, insurers tended to pay claims after patients received treatment, without requiring preapproval, and deferred to the diagnoses and treatment decisions of healthcare providers. "Rising healthcare costs, however, prompted insurers to control costs through utilization review ${ }^{12}$ and pre-certification. ${ }^{13}$

In addition, increasing numbers of ERISA plans are self-funded. ${ }^{14}$ Under a self-funded (also known as a self-insured) plan, an employer (or other plan sponsor) pays the cost of claims directly, rather than purchasing insurance on an employee's behalf. ${ }^{15}$ Self-funded plans are not considered insurance products and are therefore beyond the reach of many state insurance regulations. ${ }^{16}$ As a result, these plans have avoided insurance reform at the state level. ${ }^{17}$

communicate with and be paid directly by insurance companies for providing medical services.").

6. As discussed in Section I.A infra, the entity with decision-making power may be an insurance company, a third-party administrator, or the employer itself.

7. Id.

8. Hufford, supra note 5, at 492.

9. See, e.g., Grijalva v. Shalala, 946 F. Supp. 747,757 (D. Ariz. 1996) (explaining that a denial of preauthorization often prevents receipt of treatment due to delay).

10. 29 U.S.C. $\S \S 1001-1461$ (2006).

11. James A. Wooten, The Employee Retirement Income Security Act of 1974: A POLITICAL History 283 (2004).

12. Utilization review is the review of requested care to determine whether it is necessary, particularly with a view to controlling costs. Merriam-Webster's COllegiate Dictionary ( 11 th ed. 2008), available at $\mathrm{http} / / \mathrm{www}$.merriam-webster.com/dictionary/utilization_review.

13. Precertification is "authorization for a specific medical procedure before it is done or for admission to an institution for care." Elsevier, MosBy's MEDICAL Dictionary (8th ed. 2009), available at http://medical-dictionary.thefreedictionary.com/precertification.

14. In 2010, fifty-nine percent of covered workers were in a self-funded plan, up from fortyfour percent in 1999. The Kaiser Family Found. \& Health Research \& Educ. Trust, EMPloyer HEalth BENEFITS: 2010 ANNUAL SURVEY 154 (2010), http://ehbs.kff.org/pdf/ 2010/8085.pdf.

15. Id.

16. Id.

17. WOOTEN, supra note 11, at 284 (noting the "backlash" against ERISA's lack of remedies and the increase in reform initiatives and noting that these reforms do not reach self-funded plans). 
ERISA's regulations set out the specifics of claims processing, including guidelines that health insurance companies must follow when they establish internal rules for claims processing. The regulations set time limits for deciding claims and appeals, govern the content of notices to participants of claim denials and rights to appeal, and require consistent decisions on similar types of claims. These are largely procedural matters, but they affect the availability of benefits directly. Most denied claims are never appealed-if a claim is decided incorrectly or appeal rights are not conveyed, the incorrect denial simply stays undisturbed. $^{18}$

The current approach to claims regulation enforcement does not match the importance of these procedures in the lives of plan participants. For example, what is the consequence when a health insurance company does not abide by these claims processing regulations? What if a health insurance company improperly denies certain claims when they are initially filed, then pays those claims if they are appealed, perhaps banking on many Participants becoming discouraged and walking away without an appeal? What is the consequence if a health insurance company improperly denies a significant claim, then pays it only during litigation? As this Article will show, in each of these cases, the health insurance company suffers little or no penalty for violating claims regulations. And yet, the financial incentive to do so, thereby avoiding paying claims, is enormous. 19

For Participants, the consequences are significant. An incorrect retrospective denial or underpayment results in either the Participant or the healthcare provider absorbing the unpaid costs. ${ }^{20}$ And if the Participant is unable to absorb the cost, financial hardship or even medical bankruptcy may result. ${ }^{21}$ An incorrect prospective denial may well mean that the participant is unable to access the

18. Caroline E. Mayer, The Claim Game, AARP The MAGaZINe, Nov.-Dec. 2009, at 32 (quoting Connecticut's health care advocate Kevin Lembo as stating that ninety-six percent of denials are not appealed); General Information on How To File Insurance Appeals, ADVOCACY FOR PATIENTS WITH ChroniC ILLNESS, INC., http://www.advocacyforpatients.org/hi_file.html (last visited Mar. 25, 2011) (stating that ninety-four percent of denials are never appealed).

19. See discussion of financial incentives at infra Section I.A.

20. AM. MED. ASs'N, APPEAL THAT Claim (2008), available at http://www.amaassn.org/amal/pub/upload/mm/368/appeal-that-claim.pdf (providing examples of physician practices that routinely lose money because Payors underpay for treatments already provided); Fawn Johnson, Big Health Firms Underpay Claims, WALL ST. J., June 25, 2009, http://online.wsj.com/article/SB10001424052970204621904574248061750721736.html (noting that when Payors underpay claims, participants make up the difference; the amounts overpaid by participants are difficult to estimate).

21. Bankruptcy Reform: Hearing Before the S. Comm. on the Judiciary, 109th Cong. (2005) (statement of Professor Elizabeth Warren, Harvard Law Professor) (noting that one million people file bankruptcy each year following a serious illness and that three quarters of those people have health insurance). 
necessary care. Such a denial may be life-threatening or even fatal. ${ }^{22}$

Physicians and other healthcare providers also suffer when healthcare claims are improperly delayed or denied. Busy physician practices and other healthcare providers must devote additional time and personnel to appeals and follow-up. ${ }^{23}$ And if providers do not follow up on improperly processed claims, they risk losing significant amounts of money for services that were legitimately provided. $^{24}$

This Article advocates a new framework for the enforcement of claimsprocessing regulations. Under the current approach, most non-compliance is excused under the "substantial compliance" 25 doctrine, and even substantial departures from the claims regulations generally result in no substantive remedy. ${ }^{26}$ This approach excuses practically all instances of regulatory non-

22. In one such case, a father of four sought inpatient treatment for alcoholism; such treatment was expressly included as a term of his benefit plan. Andrews-Clarke v. Travelers Ins. Co., $984 \mathrm{~F}$. Supp. 49, 52 (D. Mass. 1997). The utilization review provider, however, "repeatedly and arbitrarily denied" the treatment and refused to authorize it. Id. Lacking a private placement for treatment, a court that had conducted a commitment hearing ordered him to treatment in a correctional facility, where he received little treatment and was abused by other inmates. Id. at 51 . The man died after consuming a six-pack of beer three weeks after his release. Id. at 52. In the subsequent lawsuit that went "right to the heart of the benefit determination process," the court dismissed the surviving spouse's wrongful death, breach of contract, and other claims, noting that ERISA provided no other choice. Id at 53. The court referred to ERISA as a "legal Pac-Man" and noted that ERISA now provides a "shield of near absolute immunity [that] cannot be justified." Id. at 63 . The court concluded that there was no legal choice but to "slam the courthouse doors in [the surviving spouse's] face and leave her without any remedy." Id. at 53. In another case, a plan administrator's delay in approving a bone marrow transplant procedure was alleged to have proven fatal, where cancer metastasized to the patient's brain during the delay period, thereby disqualifying her from having the bone marrow transplant. Bast v. Prudential Ins. Co., 150 F.3d 1003 (9th Cir. 1998) (holding that the "unfortunate consequence of the compromise Congress made in drafting ERISA" left plaintiff without a remedy).

23. "[P]hysicians and practice staff should all participate in the audit process. . . You might also consider hiring a consultant who specializes in billing and collections to assist in specified audit tasks." AM. MED. AsS'N, supra note 20, at 11.

24. See id. at 8-9 (citing numerous examples of physician practices whose claims were being underpaid, sometimes by as much as $\$ 100,000$ per month).

25. The exact contours of the "substantial compliance" doctrine depend on the court applying it and the particular circumstances of the case. Generally, however, "substantial compliance" is understood to mean technical non-compliance with the claims regulations, such that the regulation's purpose is nonetheless accomplished. See, e.g., Larson v. Old Dominion Freight Line, Inc., 277 F. App'x 318, 321-22 (4th Cir. 2008) (holding that even if the administrator's communications did not technically comply with the regulations in that they did not give the basis for the claim denial, they provided a sufficient understanding of the administrator's position and therefore substantially complied).

26. See discussion of lack of incentives to comply infra Section II.B. 
compliance and places the enforcement burden on those least able to shoulder it-the individuals seeking and paying for medical care. Instead, ERISA's goal of ensuring contracted benefits would be better served if enforcement moved to a presumed-harm approach, akin to the approach used in numerous consumer finance laws. This Article argues that the same concerns driving consumer financial protections have even greater force where healthcare is concerned.

Part I of this Article sets out the problem of improper claims processing and provides background on ERISA and its regulations. Part II examines the claims processing regulations and their current interpretation in the courts. Part III explains the case for a presumed-harm approach to enforcement of the claims processing regulations and suggests two remedies: First, non-compliance with claims processing regulations should be penalized through an expanded view of attorney's fee awards. Second, the Truth in Lending Act shows how ERISA reform could adopt the presumed-harm approach and thereby lend predictability, efficiency, and equity to the enforcement of ERISA's claims processing regulations.

\section{The Claims Processing Problem AND ERISA}

ERISA was enacted in 1974 with pension plan reform in mind. ${ }^{27}$ At the time, few imagined that ERISA would serve such a significant role with regard to healthcare. ${ }^{28}$ Since 1974 , increasing numbers of employers have redesigned their employee benefit plans as ERISA plans, in order to take advantage of the limited plaintiff remedies available under ERISA and ERISA's protection from state regulation. ${ }^{29}$ Today, ERISA governs most of America's non-Medicare healthcare coverage, ${ }^{30}$ and ERISA's regulations set the ground rules for processing

27. WOOTEN, supra note 11 , at 281 .

28. Id.

29. In a notorious example of an insurance executive's frank assessment of ERISA's advantages, the executive noted in a memo that

[t] he advantages of ERISA . . . are enormous: state law is preempted by federal law, there are no jury trials, there are no compensatory or punitive damages, relief is usually limited to the amount of benefit in question, and claims administrators may receive a deferential standard of review. . . [For a set of] 12 claim situations where we settled for $\$ 7.8$ million in the aggregate . . [i]f these 12 cases had been covered by ERISA, our liability would have been between zero and \$0.5 million.

The memorandum goes on to note: "While our objective is to pay all valid claims and deny invalid claims, there are gray areas, and ERISA applicability may influence our course of action." Memorandum from Jeff McCall to IDC Mgmt. Grp. \& Glenn Felton (Oct. 2, 1995), available at http://www.erisa-claims.com/library/Provident\%20memo.pdf.

30. The Kaiser Family Found. \& Health Research \& Educ. Trust, supra note 14. 
healthcare claims. ${ }^{31}$ As set out below, the ERISA statute's origins in reform and access to benefits have grown into a complex thicket that leaves participating employees and their beneficiaries with fewer remedies than they had before ERISA's enactment.

\section{A. The Problem: Why Claims Regulations Matter}

As written, ERISA's claims processing regulations are intended to help ensure accurate, prompt initial decisions on healthcare claims. ${ }^{32}$ The regulations set out time frames for claims processing and procedures for appealing a denial. ${ }^{33}$ They require clear communication of Participants' rights. ${ }^{34} \mathrm{~A}$ violation of claims regulations may result in an improper denial, or it may leave a Participant with insufficient information about a denial or the Participant's right to appeal. Whether or not the violation ultimately results in an improper denial, the effect is that the Participant is denied information, rights, and, potentially, coverage to which the Participant is entitled.

The regulations also allow the Participant to sue and have a federal judge decide whether the claim should have been paid after a plan administrator repeatedly denies a healthcare claim. But the vast majority of Participants whose claims are denied do not sue. ${ }^{35}$ In fact, most do not even appeal the claim internally to a plan administrator. ${ }^{36}$ Upon initial submission, healthcare claims are denied at a rate of approximately one in seven, so that two hundred million of the 1.4 billion claims submitted annually are initially denied. ${ }^{37}$ According to the American Medical Association's most recent estimate, about twenty percent of

31. The regulations derive from 29 U.S.C. $\S 1133$, which requires every employee benefit plan, in accordance with regulations of the Department, to "provide adequate notice in writing to [any] participant or beneficiary whose claim for benefits under the plan has been denied, setting forth the specific reasons for such denial, written in a manner calculated to be understood by the participant," and to "afford a reasonable opportunity to any participant whose claim for benefits has been denied for a full and fair review by the appropriate named fiduciary of the decision denying the claim." 29 U.S.C. $\S 1133$ (2006).

32. The regulations require that plan procedures "contain administrative processes and safeguards designed to ensure and to verify that benefit claim determinations are made in accordance with governing plan documents and that, where appropriate, the plan provisions have been applied consistently with respect to similarly situated claimants." 29 C.F.R. $§ 2560.503-$ l(b)(5) (2009).

33. Id. \& 2560.503-I(f), (h), (i).

34. Id. $\S 2560.503-1$ (c)(3)(iv).

35. In order to sue, participants must first exhaust their appeal rights within the plan. $I d$. $\S$ 2560.503-1(c)(3)(iii).

36. See supra note 18 and accompanying text.

37. See Mayer supra note 18. 
all healthcare claims are processed incorrectly. ${ }^{38}$ More than ninety percent of claim denials, according to most estimates, are never appealed. ${ }^{39}$ Of the denials that are appealed, about half are reversed in favor of the Participant. ${ }^{40}$

Even though so many denied claims are never appealed, health insurance companies are not penalized when claims are denied upon initial submission and paid only upon first or second appeal. ${ }^{41}$ Even a procedural violation, such as a failure to communicate appeal rights, may be excused if the error is cured at some later point. ${ }^{42}$ This regulatory approach provides no remedy for the many Participants that drop out of the appeals process at the first miscommunication.

At the same time, health insurance companies and employers offering selfinsured plans (together, "Payors") profit enormously when claims are denied or otherwise diminished. ${ }^{43}$ Empirical research links higher net profits with an increased tendency to discount or deny claims. ${ }^{44}$ Therefore, Payors, whether

38. Press Release, Am. Med. Ass'n., National Health Insurer Report Card (June 14, 2010), available at http://www.ama-assn.org/ama/pub/physician-resources/solutions-managing-your -practice/coding-billing-insurance/heal-claims-process/national-health-insurer-report-card.shtml (reporting that approximately twenty percent of claims are processed incorrectly and advocating a uniform, national set of standards for processing healthcare claims); see also Press Release, Cal. Nurses Ass'n/Nat'l Nurses Org. Comm., California's Real Death Panels: Insurers Deny $21 \%$ of Claims (Sept. 2, 2009), available at http://www.calnurses.org/media-center/press-releases/2009/ september/california-s-real-death-panels-insurers-deny-21-of-claims.html (estimating the denial rate at twenty-one percent and quoting the organization's co-president Deborah Burger, stating "[t]he routine denial of care by private insurers is like the elephant in the room no one in the present national healthcare debate seems to want to talk about").

39. See, e.g., Mayer, supra note 18 , at 32.

40. Walecia Konrad, Fighting Denied Claims Requires Perseverance, N.Y. TIMES, Feb. 6, 2010, at B6, available at http://www.nytimes.com/2010/02/06/health/06patient.html.

41. Occasionally, courts raise the argument that reputational concerns weigh against the significant financial incentives favoring aggressive claim denials. As leading ERISA scholar John Langbein notes, most potential employees accept the health insurance benefits available when they accept a particular job, and potential employees are unlikely to inquire about other employees' healthcare claims experience before accepting a job. John H. Langbein, Trust Law as Regulatory Law: The Unum/Provident Scandal and Judicial Review of Benefit Denials Under ERISA, 101 Nw. U. L. REV. 1315, 1328 (2007).

42. Wade v. Hewlett-Packard Dev. Co. LP Short Term Disability Plan, 493 F.3d 533, 539-40 (5th Cir. 2007) (holding that a plan's substantial regulatory compliance in the final level of appeal cured the non-compliance in the first two levels, in that the initial telephone contact in place of the required written notice, and the subsequent inadequate written notice, were cured by a subsequent compliant written notice at the first level of review).

43. Jeffrey D. Greenberg et al., Reimbursement Denial and Reversal by Health Plans at a University Hospital, 117 J. AM. MED. 629, 633 (2004) (finding a "strong positive correlation" between net profit margin and the adjusted odds that a plan would discount the cost of a day's stay in the hospital).

44. Id. 
administering plans or directing others to do so, have a strong incentive to act against Participants' interests. ${ }^{45}$

Whether plans are fully insured or self-insured, incorrect denials amount to enhanced profit for the would-be Payor. In the case of fully insured plans, the decision-maker and Payor are the same entity, such that money saved on participants' medical care equates to greater amounts of money available for salaries, administrative expenses, and profits. ${ }^{46}$ Accordingly, courts recognize the conflict that arises when the same entity both determines benefit eligibility and pays benefits. 47

In the case of self-funded plans, the financial conflict analysis is different, because claims processing is generally handled by a third-party administrator (TPA), at least with regard to initial claims decisions. ${ }^{48}$ There is, however, no prohibition against an employer's administering claims in-house, and some larger employers may choose to do so if they have the necessary personnel and resources to assess claims. ${ }^{49}$ Employers may rely on a TPA for utilization review as well. Where a TPA processes claims for the ultimate Payor-the employerthe conflict of interest may be less direct than if the ultimate Payor determines eligibility and then pays claims directly out of its own pocket.

But a Payor's delegation of some day-to-day plan operations to a TPA, which serves at the pleasure of the Payor, does not necessarily neutralize the conflict. While the conflict may be somewhat attenuated when the Payor does not also act as the decision-maker, the Payor may still have a hand in the process in several ways: through the terms of its relationship with the TPA, through

45. DiFelice v. Aetna U.S. Healthcare, 346 F.3d 442, 459 (3d Cir. 2003) ("ERISA's remedial scheme gives HMOs every incentive to act in their own and not in their beneficiaries' interest while simultaneously making it incredibly difficult for plan participants to pursue what meager remedies they possess, a confounding result for a statute whose original purpose was to protect employees.").

46. U.S. Dept. of Health \& Human Servs., Insurance Companies Prosper, families SUFFER, available at http://nchc.org/sites/default/files/resources/insuranceprofits.pdf (last visited Feb. 16, 2011) (noting that three of the top five insurers spent less on participant medical care, while spending more on "salaries, administrative expenses, and profits").

47. Metro. Life Ins. Co. v. Glenn, 554 U.S. 105, 112 (2008) (noting that the payor's fiduciary interest "may counsel in favor of granting a borderline claim while its immediate financial interest counsels to the contrary"). Thus, the payor has an interest "conflicting with that of the beneficiaries." Id.

48. Understanding Your Fiduciary Responsibilties Under a Group Health Plan, U.S. DEP'T OF LABOR (Oct. 2008), http://www.dol.gov/ebsa/publications/ghpfiduciaryresponsibilities.html ("Employers often hire outside professionals (sometimes called third-party service providers) ... to manage some or all of the plan's day-to-day operations.").

49. See, e.g., HEAlTH CARE ADM'RS ASS'N, http://www.hcaa.org/selffunding.html (last visited Mar. 25, 2011) (noting that employers can either retain a third-party administrator or administer claims themselves). 
influence over the TPA, or through retention of control over appealed claims. ${ }^{50}$ As one court explained, "delegation of claims administration does not negate a structural conflict outright." ${ }^{, 51}$ Although the Payor delegates claims responsibility to the TPA, the Payor may still influence the TPA's decision-making process. ${ }^{52}$ For example, in one case where the employer had delegated the decision as to whether benefits should be provided, the court found evidence that the employer still retained some oversight of the process and gave financial incentives to the TPA if the plan was administered as the employer wished. ${ }^{53}$ Thus, Payors retain control of the claims process, to varying degrees ranging from some control to considerable control, despite delegation to a TPA. ${ }^{54}$

Correct initial processing of claims is particularly important because plan administrators' decisions are given deference by the courts under ERISA. In 1989 , the Court decided that where plan terms give the plan administrator discretion to determine benefit eligibility and interpret plan terms, plan administrators' decisions should be given deference unless the decisions are arbitrary and capricious. ${ }^{55}$ Each circuit court of appeals articulates and applies the arbitrary and capricious standard slightly differently, but a decision is typically considered arbitrary and capricious if there was no reasonable basis for the decision. ${ }^{56}$ If the determination is one of medical necessity, for example, a plan administrator must take treating physicians' opinions into account, but is free to disagree with treating physicians if the plan reviewers find other evidence more compelling. ${ }^{57}$ This deferential standard applies even if the plan

50. See, e.g., Univ. Hosps. of Cleveland v. Emerson Elec. Co., 202 F.3d 839, 844 (6th Cir. 2000) (noting that even where a TPA makes the initial claims decision, a conflict may still exist if appeals are decided by a board appointed by the payor/employer). The court "should be particularly vigilant in situations where, as here, the plan sponsor bears all or most of the risk of paying claims, and also appoints the body designated as the final arbiter of such claims. Under these circumstances, the potential for self-interested decision-making is evident." $I d$.

51. Leu v. Cox Long-Term Disability Plan, No. 2:08-CV-00889-PHX-JAT, 2009 WL 2219288 , at *2 (D. Ariz. July 24, 2009).

52. Nord v. Black \& Decker Disability Plan, 296 F.3d 823 (9th Cir. 2002) (finding that a TPA merely made recommendations regarding benefit eligibility to the plan administrator while the administrator made final decisions), rev'd on other grounds, 538 U.S. 822 (2003).

53. Mazur v. Pac. Telesis Grp. Comprehensive Disability Benefits Plan, No. C07-01904 JSW 2008 WL 564796 (N.D. Cal. Feb. 28, 2008).

54. Williams v. BellSouth Telecomms., Inc., 373 F.3d 1132, 1135-37 (11th Cir. 2004) (finding that an employer had delegated claims processing to a TPA but still influenced the claims process).

55. Firestone Tire \& Rubber Co. v. Bruch, 489 U.S. 101, 109 (1989).

56. See, e.g., Gannon v. Metro. Life Ins., 360 F.3d 211, 213 (1st Cir. 2005) (noting that evidence is substantial if it "is reasonably sufficient to support a conclusion, and the existence of contrary evidence does not, in itself, make the administrator's decision arbitrary").

57. See, e.g., Love v. Dell, Inc., 551 F.3d 333, 337 (5th Cir. 2008) (reviewing plan administrator's decision for abuse of discretion and upholding plan administrator's conclusion that 
administrator both decides and pays claims, as many do. ${ }^{58}$ In such situations, there is a perfect dollar-for-dollar conflict every time a claim is granted: "[E]very dollar provided in benefits is a dollar spent by . . . the employer; and every dollar saved . . . is a dollar in [the employer's] pocket." ${ }^{, 59}$ And, as explained above, even if the plan administrator is a separate entity from the Payor, the Payor generally selects and hires the plan administrator and may well retain direct or indirect control over claims processing, such that the conflict remains. If the plan does not grant discretion to the administrator to determine benefit eligibility and interpret plan terms, then the decision must be reviewed de novo. ${ }^{60}$ In a de novo review, the court does not defer to the plan administrator's decision, but instead interprets the plan and reviews the evidence itself in order to decide the claim for benefits. ${ }^{61}$ However, the Court is increasingly narrowing the circumstances under which de novo review is available, and the Court recently reaffirmed its approval of the abuse of discretion standard and noted its disapproval of ad hoc exceptions to deferential review. ${ }^{62}$ Because of this deference and because so few Participants pursue their rights to appeal and sue, the accuracy of the initial claims decision and the communication of the Participants' rights are critically important in achieving ERISA's goal of ensuring contracted benefits. ${ }^{63}$

\section{B. ERISA's Purpose and Background}

The ERISA claims processing regulations derive from the larger ERISA scheme that was enacted in $1974 .{ }^{64}$ Congress enacted ERISA to protect Participants' interests in employer-sponsored benefit plans by setting out regulations and providing access to the federal courts. ${ }^{65}$ In enacting ERISA,

a seventeen-year-old's intensive inpatient treatment for serious mental illness and substance abuse was not medically necessary, despite treating physicians' opinion that it was).

58. See Metro. Life Ins. Co. v. Glenn, 554 U.S. 105, 120 (2008) (noting that the conflict-ofinterest concern applies to the "lion's share" of ERISA benefit denial cases).

59. Id. at 112 .

60. Id.

61. Id. at 112-13.

62. Id.

63. Health, Educ. \& Hum. Servs. Div., U.S. Gen. Accounting Office, B-276104, Employer-Based Managed Care Plans: ERISA's Effect on Remedies for Benefit Denials AND MEDICAL MALPRACTICE 25-30 (1998) (noting that the Department of Labor and others favor stronger remedies for non-compliance with the claims process, so that "upstream" compliance is improved).

64. Employee Retirement Income Security Act of 1974, Pub. L. No. 93-406, 88 Stat. 832 (1974) (codified as amended at 29 U.S.C. $\$ \S 1001-1461$ (2006)).

65. Id. $\S 1001$ ("The Congress finds . . that the continued well-being and security of millions of employees and their dependents are directly affected by these plans; . . . it is therefore desirable in the interests of employees and their beneficiaries . . . that minimum standards be provided 
Congress addressed two main risks to pension plans: the risk of default and the risk of poor administration. ${ }^{66}$ ERISA contains rules that are specific to pension plans, as well as rules that apply to both pension plans and welfare benefit plans, such as healthcare plans. ${ }^{67}$ While pension plans are vulnerable to default or insolvency risk, welfare benefit plans are exposed to the risk of poor administration in the same way as pension plans. ${ }^{68}$ For this reason, Congress brought welfare plans under ERISA's umbrella, so that ERISA's fiduciary rules would apply. ${ }^{69}$

\section{Basis in Trust Law}

In developing ERISA, Congress did not create a new legal approach, but instead imported trust law as ERISA's framework. ${ }^{70}$ ERISA sets out fiduciary duties applicable to the administration of plans ${ }^{71}$ including the rules of loyalty and prudence and the exclusive benefit rule. ${ }^{72}$ Instead of setting out all of the specific powers of trustees and other fiduciaries, Congress imported the common law of trusts to describe the responsibilities of ERISA fiduciaries. ${ }^{73}$

assuring the equitable character of such plans and their financial soundness. . . It is hereby declared to be the policy of this chapter to protect interstate commerce and the interests of participants in employee benefit plans and their beneficiaries . ..."); Aetna Health, Inc. v. Davila, 542 U.S. 200, 208 (2004); Donovan v. Dillingham, 688 F.2d 1367, 1370 (11th Cir. 1982) ("Congress enacted ERISA to protect working men and women from abuses in the administration and investment of private retirement plans and employee welfare plans.").

66. John H. Langbein, What ERISA Means by "Equitable": The Supreme Court's Trail of Error in Russell, Mertens, and Great-West, 103 CoLum. L. REV. 1317, 1322-23 (2003) (explaining that the movement that led to the passage of ERISA "effectively commenced in 1963, when the financially troubled automaker, Studebaker, defaulted on its pension plan, frustrating the support expectations of several thousand workers and retirees").

67. 29 U.S.C. $\& 1002(1)$ (stating that the term "employee welfare benefit plan" includes medical, accident, disability, death, unemployment, child care, training, scholarship, prepaid legal, and vacation benefit plans).

68. Langbein, supra note 66 , at 1323.

69. Id.

70. Firestone Tire \& Rubber v. Bruch, 489 U.S. 101, 110 (1989) ("ERISA abounds with the language and terminology of trust law" and stating that ERISA's legislative history shows that principles of trust law were meant to apply to ERISA fiduciaries); H.R. REP. No. 93-533, at 11 (1974), reprinted in 1974 U.S.C.C.A.N. 4639, 4651 ("The principles of fiduciary conduct are adopted from existing trust law, but with modifications appropriate for employee benefit plans."); Langbein, supra note 66, at 1319 ("Congress made a deliberate choice to subject these plans to the pre-existing regime of trust law rather than to invent a new regulatory structure.").

71. Varity Corp. v. Howe, 516 U.S. 489, 496 (1996).

72. 29 U.S.C. $\S 1104(a)(1)(A)$.

73. Cent. States, Se. \& Sw. Areas Pension Fund v. Cent. Transp., Inc., 472 U.S. 559, 570 (1985). 
Under ERISA, those who exercise discretion over management of the plan or who are named as fiduciaries in the plan are subject to fiduciary duties, and so is any person exercising material discretion over plan assets or administration. ${ }^{74}$ This means that the individuals who make healthcare benefit decisions are acting as fiduciaries and are bound by these duties; ERISA's legislative history supports the imposition of fiduciary duties upon those who make claims determinations and pay plan benefits. ${ }^{75}$

ERISA fiduciaries must discharge their duties with respect to the plan "solely in the interest of the participants and beneficiaries. ..." Fiduciaries are also required to carry out their duties "in accordance with the documents and instruments governing the plan[.], 77

The traditional trustee "is not permitted to place himself in a position where it would be for his own benefit to violate his duty to the beneficiaries." ${ }^{78}$ Under ERISA, however, a trustee can be in exactly that position, having financial interests directly opposed to plan Participants. ${ }^{39}$ An ERISA fiduciary can be in the position of making healthcare claims determinations that, if decided against the beneficiary, would place additional funds in the fiduciary's employer's pocket to the beneficiary's detriment. ${ }^{80}$

ERISA, therefore, imports trust law but ignores one of trust law's most important principles - the principle that plan fiduciaries should not breach their duties to beneficiaries and, certainly, should not be in a position to benefit financially from breaching those duties. Given these diametrically opposed interests and the profit-earning goals of Payors, additional incentives to comply with claims processing regulations are needed, as set out below.

74. 29 U.S.C. $\$ 1002(21)(A)$; Langbein, supra note 66 , at 1324-25.

75. See, e.g., H.R. REP. No. 93-1280, at 301 (1974) (Conf. Rep.), reprinted in 1974 U.S.C.C.A.N. 5038, 5081 (discussing procedures for delegating fiduciary duties, such as "allocation or delegation of duties with respect to payment of benefits"); 120 CONG. REC. 29,929 (1974) (remarks of Sen. Williams) (stating that ERISA imposes "strict fiduciary obligations upon those who exercise management or control over the assets or administration of an employee pension or welfare plan ....").

76. 29 U.S.C. $\S 1104(a)(1)$

77. $1 d . \S 1104(\mathrm{a})(1)(\mathrm{D})$.

78. Pegram v. Herdich, 530 U.S. 211, 225 (2000) (quoting IIA WilLIAM F. FRATCHER, SCOTT ON TRUSTS $\S 170$ (4th ed. 1998)).

79. Id.

80. See, e.g., Metro. Life Ins. Co. v. Glenn, 554 U.S. 105, 120 (2008) (Roberts, J., concurring in part and concurring in the judgment) (noting that the conflict-of-interest concern applies to most ERISA benefit denial cases). 


\section{Preemption and Enforcement}

ERISA preempts all state laws that "relate to" ERISA plans, as well as any cause of action that duplicates or supplants a claim under ERISA's enforcement provisions. ${ }^{81}$ ERISA thus takes away most state-law claims and remedies, but courts struggle with what, if anything, ERISA provides in their place. Indeed, the preemption provision often takes away state-law claims but gives no replacement claim at all. ${ }^{82}$ ERISA's preemption provision was always intended to be broad. ${ }^{83}$ But, Congress also intended that ERISA would be supplemented by a federal common law, developed in the federal courts and tailored to ERISA and its purposes. ${ }^{84}$ As explained below in Subsection II.B.4, no such remedial, tailored federal common law has emerged.

The remedies available under ERISA are notoriously limited, heightening the need for plan administrators to determine initial claims and appeals accurately. ${ }^{85}$ ERISA typically provides little relief when administrators violate claims regulations by, for example, failing to give adequate notice about appeals or reviewing a claim improperly, even though these violations often leave legitimate claims unpaid.

ERISA contains an integrated civil enforcement scheme consisting of the six provisions found in section 1132(a) of the statute; these are the exclusive means of enforcing ERISA's provisions. ${ }^{86}$ ERISA's enforcement provisions have taken on particular importance because ERISA takes away other traditional state law causes of action and remedies. ${ }^{87} \mathrm{~A}$ wronged Participant cannot sue immediately

81. 29 U.S.C. $\S \S 1132,1144$.

82. Corcoran v. United Healthcare, Inc., 965 F.2d 1321, 1338 (5th Cir. 1992) ("[T]he result ERISA compels us to reach means that the Corcorans have no remedy, state or federal, for what may have been a serious mistake."); see also WOOTEN, supra note 11, at 283-84 (discussing the limited remedies available to plan participants).

83. WOOTEN, supra note 11 , at 282.

84. Upon presenting the Conference Report to the full Senate, principal sponsor Senator Javits stated, "It is also intended that a body of Federal substantive law will be developed by the courts to deal with issues concerning rights and obligations under private welfare and pension plans." 120 Cong. ReC. 29, 942 (1974) (statement of Sen. Javits); see also Mass. Mut. Life Ins. Co. v. Russell, 473 U.S. 134, 156 (1985) (Brennan, J., concurring) (discussing Congress's intention that the courts would develop a federal common law of ERISA).

85. See, e.g., DiFelice v. Aetna U.S. Healthcare, 346 F.3d 442, 456 (3d Cir. 2003) (Becker, J., concurring) ("[V]irtually all state law remedies are preempted [by ERISA] but very few federal substitutes are provided.").

86. Aetna Health Inc. v. Davila, 542 U.S. 200, 209 (2004) (citing Pilot Life Ins. Co. v. Dedeaux, 481 U.S. 41, 55 (1986)).

87. Pilot Life Ins. Co. v. Dedeaux, 481 U.S. at 55 ("The deliberate care with which ERISA's civil enforcement remedies were drafted and the balancing of policies embodied in its choice of remedies argue strongly for the conclusion that ERISA's civil enforcement remedies were intended 
in federal court but must first exhaust administrative remedies within the plan. ${ }^{88}$

Faced with a claim denial, a Participant must first appeal according to a plan's internal procedures. An internal appeal generally results in appealing a claim once or twice within the health insurance company or third-party administrator's system. ${ }^{89}$ After exhausting these administrative remedies, the Participant is then eligible to file an ERISA lawsuit in federal court. Under the basic claim for benefits, a participant brings a cause of action under ERISA section 501(a)(1), for "benefits due." This provision permits recovery of the benefit's value. ERISA contains an attorney's fee provision permitting the award of attorney's fees to either party, within the court's discretion. 90

ERISA provides that plaintiffs can recover equitable relief under certain circumstances. $^{91}$ Despite careful and convincing scholarship to the contrary, the Supreme Court does not include a make-whole remedy within those remedies. ${ }^{92}$ Thus, if the Participant wins the lawsuit, the Participant is generally awarded the value of the benefit and nothing more. ${ }^{93}$ Under current Supreme Court authority,

to be exclusive."). This exchange of traditional remedies for ERISA remedies has come to be known as the "ERISA bargain"- the idea that in exchange for security in benefits, employees gave up their traditional state-law remedies. The "ERISA bargain" is recognized by courts and is frequently cited when the intersection between ERISA's broad preemption provision and the lack of any equivalent federal remedy results in harms without remedies:

Plaintiffs and employees similarly situated receive the many protections of ERISA in exchange for certain rights to sue under previous federal and state law. Congress has decided that they are better off for the bargain. Whatever injustices this scheme may tolerate in isolated instances are more than compensated by the general security provided to pension rights under ERISAplaintiffs themselves are now enjoying the fruits of rights which Caterpillar could not and cannot divest. If workers deserve further protection, it will be up to Congress to provide it.

Willams v. Caterpillar, Inc., 720 F. Supp. 148, 152 (N.D. Cal. 1989).

88. LaRue v. DeWolff, Boberg, \& Assocs., 552 U.S. 248, 259 (2008).

89. In some circumstances, Participants can also submit denied claims for independent, external review. Karen Politz et al., Assessing State External Review Programs and the Effects of Pending Federal Patients' Rights Legislation, KAISER FAmily Foundation (Revised May 2002), http://www.kff.org/insurance/externalreviewpart2rev.pdf. On average, external reviews overturn forty-five percent of denials submitted to them. Id at v-vi. External reviews are, however, complicated to access and underused; in New York, for example, only 902 consumers filed for external review in the reporting year ending in June 2000, although 8.4 million consumers are covered by the external review law in that state. $I d$.

90. 29 U.S.C. $\S 1132(\mathrm{~g})(2006)$.

91. Id. $\S 1132(\mathrm{a})(3)(\mathrm{B})$.

92. WOOTEN, supra note 11 , at 282.

93. See, e.g., Mass. Mut. Life Ins. Co. v. Russell, 473 U.S. 134, 148 (1985) (permitting no extra-contractual damages for delayed processing of claim). 
ERISA does not contemplate extra-contractual damages for consequential harms, even when the result is that the Participant is not made whole. ${ }^{94}$ The Participant might also receive attorney's fees at the court's discretion. ${ }^{95}$

Thus, if a claim is improperly denied, and the Participant appeals within the plan, pursues a federal lawsuit and wins, the Participant stands to gain only the value of the benefit that was denied. Attorney's fees may be awarded, but are not presumed. The current lack of consequential and punitive damages means that the improper denial is typically not separately and distinctly penalized at all. Because of these features of the ERISA regime, the accuracy and completeness of the initial claims review is doubly important and should be incentivized accordingly.

\section{A REGULATORY FRAMEWORK WITH LITTLE INCENTIVE TO COMPLY}

As currently interpreted, the regulations that govern claims processing do not contain incentives to comply with any precision. Unless the regulatory violation results in serious, direct harm, noncompliance is generally excused under the "substantial compliance" doctrine set out below. Even where noncompliance is substantial, ERISA provides no substantive remedy. In most cases, even after a Participant has sued in federal court, the plan administrator is not penalized but is simply instructed to go back and take the action that it should have taken in the first instance.

\section{A. The Regulatory Background}

Department of Labor (DOL) regulations set out a framework of minimum standards for processing healthcare benefit claims. ${ }^{96}$ ERISA authorizes these regulations and provides that every employee benefit plan shall give adequate notice of a claim denial and afford a reasonable opportunity for a full review of denied claims. ${ }^{97}$ Participants must exhaust these internal processes before filing suit in federal court, but the internal claims and appeal processes are deemed exhausted in the absence of strict compliance with the claims regulations. ${ }^{98}$

The PPACA added new requirements for internal claims review and appeal

94. See, e.g., Mertens v. Hewitt Assocs., 508 U.S. 248, 255 (1993).

95. 29 U.S.C. $\$ 1132(\mathrm{~g})$.

96. Most of the regulations apply to claims for healthcare benefits but also to claims for benefits under other types of ERISA plans. Aetna Health, Inc. v. Davila, 542 U.S. 200, 220 (2004) ("These regulations, on their face, apply equally to health benefit plans and other plans, and do not draw distinctions between medical and nonmedical benefits determinations.").

97. 29 U.S.C. $\S 1133$.

98. 29 C.F.R. $\S 2590.715-2719$ (b)(2)(ii)(F) (2010) (providing that where a plan fails to establish or follow claims procedures consistent with the regulation's requirement, a claimant shall be deemed to have exhausted the internal procedures and the claim is to be reviewed de novo). 
processes, as well as external review. ${ }^{99}$ The new regulations apply to employee benefit plans (and other types of group health plans) for plan years beginning September 23, 2010. ${ }^{100}$ The regulations do not apply to "grandfathered" plans, that is, plans that were in effect before the enactment of the PPACA that have not been significantly altered in terms of coverage or benefits. ${ }^{101}$

Under the regulations, plan administrators have an obligation to maintain reasonable claims procedures. ${ }^{102}$ Claims procedures are defined as unreasonable if they contain any provision unduly inhibiting the processing of claims, such as requiring a person to receive prior authorization when the person is unconscious or requiring that a person pay a fee to appeal a claim denial. ${ }^{103}$ Procedures must contain "administrative processes and safeguards" designed to ensure that plan provisions are interpreted and applied consistently, and that decisions are made according to plan documents. ${ }^{104}$ Claims for benefits must be processed within thirty days after the plan's receipt of the claim, unless the plan administrator determines that a fifteen-day extension is necessary and sends written notice of the extension. ${ }^{105}$ The statute does not require Payors to pay interest on late-paid claims.

If a claim is denied, a written denial must set out the basis for the denial, reference the specific plan provision upon which the decision was based, and give a description of any additional material or information needed to pursue the claim. ${ }^{106}$ If an internal rule, guideline, protocol, or similar criterion was relied upon in the denial, that rule or criterion must be disclosed to the claimant upon request. ${ }^{107}$ In addition, the notice must be written "in a manner calculated to be

99. The PPACA (along with the Health Care and Education Reconciliation Act (HCERA)) created authority for additional internal and external claims and appeals to be issued jointly by the Department of Treasury's Internal Revenue Service, the Department of Labor's Employee Benefits Security Administration (EBSA), and the Department of Health and Human Services (HHS). These agencies published their interim final rules with a request for comments on July 23, 2010. The interim final regulations are published at 26 C.F.R. $\S 54.9815-2719$ T (2010) (IRS), 29 C.F.R. $\S$ 2590.715-2719 (EBSA), and 45 C.F.R. $\S 147.136$ (HHS). Citations herein will be to the EBSA version of the regulations.

100. 29 C.F.R. $\S 2590.715-1251$ (d).

101. Id. § 2590.715-1251(c); see also Interim Final Rules for Group Health Plans and Health Insurance Issuers Relating to Internal Claims and Appeals and External Review Processes Under the Patient Protection and Affordable Care Act, 75 Fed. Reg. 43,330, 43,332 (July 23, 2010).

102. 29 C.F.R. \& 2560.503-1(b).

103. Id. $\S 2560.503-1(\mathrm{~b})(3)$.

104. Id. $\S 2560.503-1(\mathrm{~b})(5)$.

105. Id. § 2560.503-1(f)(2)(iii)(B).

106. Id. $\S 2560.503-1(\mathrm{~g})(1)$.

107. Id. § 2560.503-1(g)(v)(A), (j)(5)(i); see also FAQs About the Benefit Claims Procedure Regulation, U.S. DEP'T OF LABOR, http://www.dol.gov/ebsa/faqs/faq_claims_proc_reg.html (last visited April 12, 2011). ("The [D]epartment [of Labor] also has taken the position that internal 
understood by the claimant." 108 The notice must also contain appropriate information as to the steps required if the Participant wishes to submit the claim for review. ${ }^{109}$ When benefits are denied, the plan must afford the Participant the opportunity for a full and fair review. ${ }^{10}$

The new regulations expand the definition of adverse benefit determination to include a coverage rescission (a cancellation or discontinuance of coverage), such that rescissions of coverage are subject to internal review just as any other adverse benefit determination would be. ${ }^{11}$ Notably, the regulations revise the conflict-of-interest rules so that compensation of claims-processing personnel cannot be directly tied to the proportion of claims denied. ${ }^{112}$ All of these new regulations amount to progress for the plan Participant-but the lack of compliance still results in no direct, substantive remedy. The new regulations also expand the availability of external review of denied healthcare claims. Plans and issuers not presently subject to a state external review process will be subject to a federal process. ${ }^{113}$ The preamble to the regulations explains that ERISA preemption prevents a state external review process from applying to most selfinsured plans and that these plans are now subject to the federal external review process. ${ }^{14}$ An external review process, however, represents yet another step that Participants must take in order to reverse an improperly denied claim.

To fully protect Participants, many of whom will never follow up on denied claims, Payors must be incentivized to comply with the regulations by accurately processing and properly approving claims in the first place.

\section{B. Little Incentive To Comply}

While the regulations set out specific requirements for claims processing,

rules, guidelines, protocols, or similar criteria would constitute instruments under which a plan is established or operated within the meaning of section 104(b)(4) of ERISA and, as such, must be disclosed to participants and beneficiaries.").

108. 29 C.F.R. $\S 2560.503-1(\mathrm{~g})$.

109. Under the regulations applicable to this section, the denial notice must contain: (1) the specific reason or reasons for the denial; (2) specific reference to the pertinent plan provisions on which the denial is based; (3) a description of any additional material or information necessary for claimant to perfect the claim and an explanation of why such information is necessary; and (4) appropriate information as to the steps to be taken if the participant or beneficiary wishes to submit his or her claim for review. Id.

110. Id. $\$ 2560.503-1(\mathrm{~h})$.

111. Id. § 2590.715-2719(a)(2)(i).

112. Id. $\$ 2590.715-2719$ (b)(2)(ii)(D).

113. Id. $\$ 2590.715-2719$ (d).

114. Interim Final Rules for Group Health Plans and Health Insurance Issuers Relating to Internal Claims and Appeals and External Review Processes Under the Patient Protection and Affordable Care Act, 75 Fed. Reg. 43,330 (July 23, 2010). 
Participants have little recourse when plan administrators do not comply. Many violations are excused through the generous "substantial compliance" doctrine; more serious or continuing process violations are often conflated with the claim denial at issue and rarely result in an independent, substantive remedy. Only the most flagrant violations provoke a targeted judicial response, and even then, the remedy is almost always procedural rather than substantive. ${ }^{115}$ The claim may be returned to the plan administrator for processing in compliance with the plan terms and ERISA regulations, but the Participant receives no compensation for the delay or for the time and effort devoted to appealing the claim and filing a lawsuit.

The regulations as currently interpreted provide little incentive to reject the following strategic approaches to payment of healthcare claims:

- Denying a claim incorrectly upon initial filing, then, if the Participant appeals, paying the claim upon first-level internal appeal. ERISA regulations do not provide for any penalty in this situation; moreover, attorney's fees are not available during the administrative phase. ${ }^{116}$ This approach would reduce the number of claims ultimately paid, because a high percentage of Participants do not appeal. ${ }^{117}$

- Denying certain types of claims incorrectly upon initial filing, then paying them during litigation. This approach results in practically no penalty at all to the plan administrator, unless the plaintiff persists in the litigation and is awarded attorney's fees. ${ }^{118}$ Again, this approach would reduce the number of claims paid, because a high percentage of Participants do not appeal.

- Paying claims outside the regulatory deadlines. Any single instance of delayed payment is likely to be excused within the "substantial compliance" doctrine. ${ }^{19}$

115. See, e.g., Wade v. Hewlett-Packard Dev. Co. LP Short Term Disability Plan, 493 F.3d $533,540$ (5th Cir. 2007) (“' $\mathrm{F}]$ ailure to fulfill procedural requirements generally does not give rise to a substantive damage remedy." (quoting Hines v. Mass. Mut. Life Ins. Co., 43 F.3d 207, 211 (5th Cir. 1995))).

116. See, e.g., Parke v. First Reliance Standard Life Ins. Co., 368 F.3d 999, 1011 (8th Cir. 2004) ("We join the Second, Fourth, Sixth, and Ninth Circuits in holding that term 'any action' in 29 U.S.C. $\$ 1132(\mathrm{~g})(1)$ does not extend to pre-litigation administrative proceedings.").

117. As set out in Section I.A, an estimated ninety percent of denied claims are not appealed.

118. See, e.g., Schoedinger v. United Healthcare, No. 4:04-cv-664 SNL, 2006 WL 3803935 (E.D. Mo. Nov. 6, 2006) (awarding fees where Payor paid some claims during litigation).

119. See infra Subsection I.B.1. If a Payor does not have reasonable claims procedures consistent with the regulation, the Participant may elect to proceed directly to federal court. 29 C.F.R. $\S 2560.503-1(1)$. Given the low percentages of denied claims that are appealed, however, proceeding to file a federal lawsuit appears not to be a preferable solution for many plan participants. 
- Failing to communicate the basis for the claim denial or the Participant's right to appeal. If such a failure comes to light as part of a claims denial, the omission is likely to be excused under the "substantial compliance" doctrine. ${ }^{120}$ If the Participant suffers consequential harm due to lack of disclosure, consequential damages are unavailable under current ERISA law. ${ }^{121}$

As described below, these strategies and other kinds of non-compliance are insufficiently addressed by the current regulations and ERISA's enforcement regime. Indeed, ERISA, as currently interpreted, effectively invites such strategic approaches to claims processing.

\section{The "Substantial Compliance" Doctrine Sets the Bar Low}

When Participants progress through the internal appeals process and on to federal court, the court first determines whether the non-compliance was substantial and whether the administrator complied with the regulations' purpose. In the case of non-substantial violations, courts apply the judicially created "substantial compliance" doctrine, which excuses many instances of noncompliance. This doctrine relaxes the technical requirements, excusing noncompliance so long as a "meaningful dialogue" between plan administrator and Participant takes place. ${ }^{123}$ Depending on the particular court's analysis, the "substantial compliance" doctrine has the potential to excuse strict compliance or compliance with multiple regulations. ${ }^{124}$ A Payor can, for example, delay a decision on the claim beyond the regulatory deadlines and still be within

120. See infra Section I.B.

121. See, e.g., Mertens v. Hewitt Assocs., 508 U.S. 248, 255 (1993).

122. See, e.g., Langbein, supra note 41, at 1318-33 (detailing the Unum/Provident bad-faith denial scandal and explaining the dangers of plan administrators both deciding and paying claims).

123. See, e.g., Robinson v. Aetna Life Ins. Co., 443 F.3d 389, 392 (5th Cir. 2006) ("Challenges to ERISA procedures are evaluated under the substantial compliance standard."); Lacy v. Fulbright \& Jaworski, L.L.P. Long Term Disability Plan, 405 F.3d 254, 256-57 (5th Cir. 2005) (holding that where a notice of denial of benefits did not strictly comply with DOL Regulations, it was sufficient to trigger appeal deadlines and only substantial rather than strict compliance with ERISA $\S 1133$ and DOL Regulation $\S 2560.503-1(\mathrm{f})$ was required).

124. See, e.g., Larson v. Old Dominion Frieght Line Inc., 277 F. App'x 318, 321 (4th Cir. 2008) (holding that even if the Administrator's communications did not technically comply with the regulations in that they did not give the basis for the claim denial, they provided a sufficient understanding of the Administrator's position and therefore substantially complied); Wade v. Hewlett Packard Dev. Co. LP Short Term Disability Plan, 493 F.3d 533, 539-40 (5th Cir. 2007) (excusing multiple failures to comply with claims regulations under the substantial compliance doctrine, when the administrator's oral rather than written notice did not comply, a subsequent denial letter did not list the plan criteria or reasons for denial, and it did not specify what information the plaintiff should submit to perfect an appeal). 
"substantial compliance" so long as information is still being exchanged with the Participant. ${ }^{125}$

In addition, non-compliance with the regulations at initial levels of appeal may be excused if the plan administrator's acts during a subsequent level of appeal effectively cure the initial non-compliance. ${ }^{126}$ The Fifth Circuit Court of Appeals reasoned that this approach is in keeping with the regulations' goal of encouraging a meaningful dialogue rather than any particular technical compliance. ${ }^{127}$ Significantly, however, this ability to later "cure" any earlier regulatory non-compliance essentially gives companies a second chance to comply, negating the importance of strict initial compliance.

\section{Substantial Noncompliance Results in Remand Rather Than a Substantive Remedy}

Even significant regulatory violations rarely trigger a substantive remedy. ${ }^{128}$ Remand to the plan administrator for a full and fair review is the most common remedy for substantial regulatory noncompliance. ${ }^{129}$ But the regulatory violation itself usually makes little substantive difference to the outcome, because the regulatory violation tends to be conflated with the accompanying improper denial of benefits. ${ }^{130}$ Indeed, there is no clear agreement as to whether regulatory non-

125. Gilbertson v. Allied Signal Inc., 328 F.3d 625, 634-35 (10th Cir. 2003).

126. Wade, 493 F.3d at 540 (holding that a plan's substantial regulatory compliance in the final level of appeal cured the non-compliance in the first two levels; i.e., initial telephone contact in place of a required written notice was cured by a subsequent written notice).

127. Id.

128. See, e.g., Lafleur v. La. Health Serv. \& Indem. Co., 563 F.3d 148, 157 (5th Cir. 2009) (" $[\mathrm{F}]$ ailure to fulfill procedural requirements generally does not give rise to a substantive damage remedy." (quoting Wade 493 F.3d at 540)); Hines v. Mass. Mut. Life Ins. Co., 43 F.3d 207, 211 (5th Cir. 1995) (finding no violation where an employer failed to notify an employee of a change in his health insurance policy); Duncan v. Assisted Living Concepts, Inc., No. Civ. A. 3:03-CV1931 N, 2005 WL 331116, at *4 (N.D. Tex. Feb. 10, 2005) ("Procedural violations of ERISA do not entitle the plan beneficiary to a substantive remedy unless the beneficiary can prove continuous violations resulting in some prejudice to the beneficiary.").

129. See Lafleur, 563 F.3d at 157 (explaining that remand is typically appropriate and preferable to substantive remedy).

130. Where, for example, an administrator changed the basis for its denial of disability benefits and failed to identify its vocational expert as specifically required by the regulations, the Fifth Circuit found that defendant, Aetna Life Insurance Company, had violated the claims regulations in a manner that constituted "more than mere technical noncompliance." Robinson $v$. Aetna Life Ins. Co., 443 F.3d 389, 394 (5th Cir. 2006); see also Aetna Health Inc. v. Davila, 542 U.S. 200, 220 (2004) (noting that the regulations "apply equally to health benefit plans and other plans, and do not draw a distinction between medical and nonmedical benefits determinations"). But despite this clear violation, the court imposed no remedy to address this violation as beyond the 
compliance can independently result in a remedy at all. ${ }^{131}$

Without any such remedy, administrators perpetuating the vast majority of claims regulations violations tend to suffer no effects other than to be instructed to do what they should have done in the first place. For example, an administrator who fails to provide the full and fair review of a claim as required by ERISA is frequently ordered to go back and conduct the same full and fair review that it should originally have conducted. ${ }^{132}$ Likewise, although the claims regulations clearly set out deadlines for making claims decisions, in case after case, administrators suffer no consequence from ignoring the regulations. Instead, the courts most often simply instruct the administrator to approve the initially denied claim, providing the administrator more time in which to do so. ${ }^{133}$

When a claim decision is delayed beyond the regulatory deadlines, there is no penalty except that the claim is "deemed denied" so that the Participant can immediately seek relief in the federal courts. ${ }^{134}$ Even where claims on internal

award of benefits that would have resulted anyway. See Robinson, 443 F.3d at 397. The court maintained the abuse of discretion standard of review, slightly modified due to the Payor's dual role as administrator and insurer. $I d$. at 395 . The court entered judgment for the Participant, based on the fact that there was no evidence in the record to support the defendant's decision. Id. at 395. The regulatory violation, therefore, did not alter the outcome that would have occurred without the violation.

131. The Fifth Circuit has discussed, but not directly addressed, whether the court would entertain a remedy for a breach of the regulations or whether there was in fact any legal basis for such a remedy. Custer v. Murphy Oil USA, Inc., 503 F.3d 415, 422 n.5 (5th Cir. 2007) ("[W]e make no holding on the difficult question of what remedy, if any, ERISA provides for a violation of its reporting and disclosure requirements.").

132. See, e.g., Smith v. Cont'l Cas. Co., 450 F.3d 253, 265 (6th Cir. 2006) (remanding for the entry of an order that the Plan Administrator reconsider the plaintiff's disability claim where the Plan Administrator had failed to conduct a full and fair review, thus abusing its discretion, in the first instance); Weaver v. Phx. Home Life Mut. Ins. Co., 990 F.2d 154, 159 (4th Cir. 1993) ("Normally, where the plan administrator has failed to comply with ERISA's procedural guidelines and the plaintiff/participant has preserved his objection to the plan administrator's noncompliance, the proper course of action for the court is remand to the plan administrator for a "full and fair review."); VanderKlok v. Provident Life \& Accident Ins. Co., 956 F.2d 610, 616-17 (6th Cir. 1992) (holding that the Plan Administrator failed to comply with section 1133 , reversing and remanding the benefits decision for a full and fair review); Duncan, 2005 WL 331116, at *4 (ordering the plan administrator to reconsider the plaintiff's administrative appeal where the plan administrator had failed to conduct a full and fair review, thus abusing its discretion, in the first instance); Hamilton v. Mecca, Inc., 930 F. Supp. 1540, 1552 (S.D. Ga. 1996).

133. Nave v. Fortis Benefits Ins. Co., No. C.A. 98-3960, 1999 WL 238949, at *5 (E.D. Pa. Mar. 30, 1999) (holding that where insurer had failed to make its decision within the regulatory deadline and had given no notice of any special circumstances requiring an extension the insurer had "neither strictly nor substantially complied" with section 2560.503-1(h) the equitable result was to dismiss plaintiff's lawsuit and give Payor another fourteen days to make its decision).

134. Mass. Mut. Life Ins. Co. v. Russell, 473 U.S. 134, 144 (1985) (holding that a claim is 
appeal are deemed denied due to administrator inaction, thereby forcing Participants to go to federal court to even receive a decision on the benefit claim, the deferential standard of review applied to the majority of initial denials is generally left intact. ${ }^{135}$ Thus, the Participant, who may have been forced to seek relief in federal court in order to receive a decision on a relatively small dollar amount, can still be denied that relief.

\section{The Most Flagrant Violations Do Not Result in a Substantive Remedy}

Even the most serious and continuing violations of ERISA claims regulations rarely result in a substantive remedy. ${ }^{136}$ The "paradigmatic example" of this most serious type of violation is the Blau case, in which "the defendants failed to comply with virtually every applicable mandate of ERISA."137 In that case, participants were denied benefits under a welfare plan. ${ }^{138}$ Upon litigation of the denial, the court found that the claims procedure did not exist in any recognizable form: "[T]here was no summary plan description, no claims procedure, and no provision to inform participants in writing of anything. [The] claims procedure fail[ed] simply because there was none." "39 The court noted that where procedural violations are so extreme, they "alter the very balance of knowledge and rights between covered employees and their employer." 140

For extreme cases such as these, the Fifth Circuit Court of Appeals, for example, contemplates a substantive remedy-in the form of a retroactive

treated as being denied after the regulatory deadlines pass, enabling the claimant to bring a civil action to have the claim's merits determined by the court); see also 29 C.F.R. $\S 2560.503-1(\mathrm{~h})(4)$ (2010) (governing regulatory deadlines).

135. Gilbertson v. Allied Signal Inc., 328 F.3d 625 (10th Cir. 2003). But see Jebian v. Hewlett-Packard Co. Employee Benefits Organization Income Protection Plan, 349 F.3d 1098 (9th Cir. 2002) (applying de novo standard where internal appeal was not decided within applicable deadline).

136. See, e.g., Lafleur v. La. Health Serv. \& Indem. Co., 563 F.3d 148, 157 (5th Cir. 2009) (noting that substantive damages for a flagrant regulatory violation could include retroactive reinstatement of benefits but that the court "ha[s] not fully identified the scope of available remedies" for procedural violations); Abatie v. Alta Health \& Life Ins. Co., 458 F.3d 955, 971 (9th Cir. 2006) (holding that the most flagrant disregard for claims regulations can result in de novo review of the plan administrator's decision; citing no possibility of a substantive remedy); Bard v. Bos. Shipping Ass'n, 471 F.3d 229, 244 (1st Cir. 2006) (striking evidence and awarding benefits based on remaining evidence where procedural violations were "serious, had a connection to the substantive decision reached, and call[ed] into question the integrity of the benefits-denial decision itself').

137. Blau v. Del Monte Corp., 748 F.2d 1348, 1353 (9th Cir. 1984).

138. Id.

139. Id.

140. Id. 
reinstatement of benefits - but has not yet seen cause to impose it. ${ }^{141}$

A severe procedural violation can result in the denial decision being treated with less deference, lowering the standard of review and leading the courts to conduct a de novo review of the administrator's denial of benefits. ${ }^{142}$ The reasoning is that by ignoring the claims procedures, the administrator has essentially failed to exercise its contractually accorded discretion, such that there is no exercise of discretion for the court to review. ${ }^{143}$ The administrator may also have violated the procedures mandated by ERISA in a way that is "so flagrant as to alter the substantive relationship between the employer and employee, thereby causing the beneficiary substantive harm." 144 The altered standard of review does not of course necessarily result in any award of benefits or any other remedy: if a de novo review does not uncover any error in the denial of benefits, the denial remains intact and no remedy is given.

Even this relatively slight remedy may be in doubt. In a recent opinion, the Supreme Court suggested that an administrator's failure to abide by fiduciary duties should not result in a de novo standard of review. ${ }^{145}$ The Court examined the effect of the conflict of interest resulting from an insurer acting as the plan administrator, and whether that dual role should imply a lowering of the standard of review from abuse of discretion to de novo. ${ }^{146}$ The Court held that the abuse of discretion standard should remain intact, but that the administrator's conflict of interest should be a factor in determining whether the administrator abused its discretion in denying the claim. ${ }^{147}$ Given this adherence to the abuse of discretion standard in the case of a conflict of interest, the Court could accordingly find that a procedural violation should likewise be a part of the review, rather than a reason to alter the standard. ${ }^{148}$

141. Lafleur, 563 F.3d at 157 (noting that substantive damages for a flagrant regulatory violation could include retroactive reinstatement of benefits, but that the court "[has] not fully identified the scope of available remedies" for procedural violations).

142. See Abatie v. Alta Health \& Life Ins. Co., 458 F.3d 955, 971 (9th Cir. 2006) ("When an administrator engages in wholesale and flagrant violations of the procedural requirements of ERISA, and these acts in utter disregard of the underlying purpose of the plan as well, we review de novo the administrator's decision to deny benefits."). Contra Lafleur, 563 F.3d at 159 ("[W]e have never definitively rejected the availability of this remedy, [but] we have previously refused to apply it.").

143. Abatie, 458 F.3d at 972.

144. Duvall v. Reliance Standard Life Ins. Co., 646 F. Supp. 2d 1188, 1202 (E.D. Cal. 2009) (quoting Gatti v. Reliance Standard Life Ins. Co., 415 F.3d 978, 985 (9th Cir. 2005)).

145. Metro. Life Ins. Co. v. Glenn, 554 U.S. 105, $115-16$ (2008).

146. Id.

147. Id. at 108 .

148. See, e.g., Duvall v. Reliance Standard Life Ins. Co., 646 F. Supp. 2d 1188, 1198 (E.D. Cal. 2009) (suggesting that Glenn, 554 U.S. at 128, abrogated the proposed lowering of the standard of review for procedural violations set out in Abatie, 458 F.3d at 971). 
In a small minority of cases, courts have viewed a violation of the claim processing regulations alone as an abuse of discretion that could justify an award of benefits. But in these cases, the violation of regulations still did not result in a substantive remedy, because in each case the benefits should have been awarded on the merits anyway. Thus, the defendant again does not suffer any independent penalty for failing to follow the claims regulations, because the benefits should have been awarded in the first place. ${ }^{149}$

Where, for example, a defendant disability insurance company failed to obtain the X-rays that it should have obtained to properly assess plaintiff's claim, the court entered judgment for the plaintiff and cited its intention to create a deterrent effect towards other insurers. ${ }^{150}$ The court did not use the plan's failure to obtain information as a means of lowering the applicable standard of review. Instead, it applied the abuse of discretion standard and found that the defendant had abused its discretion by failing to provide a full and fair review. ${ }^{151}$ The court noted, however, that the plaintiff was in fact disabled, meaning that the effect of the court's decision was simply that the administrator was forced to do what it should have done in the first instance. ${ }^{152}$

\section{Freestanding Claims for Breach of Fiduciary Duty Fail To Address Regulatory Non-compliance}

Section 1132(A)(3)(b) of ERISA is a "catch-all" provision that gives Participants a potential cause of action for breaches of fiduciary duty such as regulatory non-compliance; injunctive and other equitable remedies are

149. Salley v. E.I. DuPont de Nemours \& Co., 966 F.2d 1011, 1015 (5th Cir. 1992) (holding that plan administrator's failure to obtain records from child's second and third hospitalization amounted to abuse of plan administrator's discretion and awarding benefits and attorney's fees to Participant). In this case, the treating physicians agreed that the Participant's hospitalization was medically necessary, while the physicians reviewing the claim for the plan said that the hospitalization was not medically necessary. Id. The reviewing physicians had neither examined the Participant nor obtained records regarding two of the three hospitalizations. The court noted that these records would have shown that the hospitalizations were medically necessary. Id.

150. Beauvais v. Citizens Fin. Group Inc., 418 F. Supp. 2d 22, 33 (D.R.I. 2006). The court's judgment included an award of past and future disability benefits (because the disability was supported by medical evidence), medical benefits under a plan for which the defendant had been found ineligible due to her lack of disability status, and attorney's fees. The court expressed disapproval of the insurer's actions and awarded attorney's fees and reinstated plaintiff's medical benefits. In awarding attorney's fees, the court noted that such a remedy would serve as a deterrent to other plan administrators inclined to deny benefits based on a failure to produce records they never requested, "a deterrent that will benefit all plan participants." $I d$. at 33.

151. Id. at 31 .

152. Id. 
available. ${ }^{153}$ But this cause of action is not an easy fit to remedy regulatory noncompliance, and, in addition, this provision's interpretation has proven extremely complex-a "virtual legal labyrinth." 154

The "catch-all" provision provides an avenue to remedy breaches of plan terms and regulations. This section gives Participants the right to bring a civil action " $(\mathrm{A})$ to enjoin any act or practice which violates any provision of this title or the terms of the plan, or (B) to obtain other appropriate equitable relief (i) to redress such violations or (ii) to enforce any provisions of this title or the terms of the plan." 155 This section is described as a "safety net, offering appropriate equitable relief for injuries caused by violations that other recourse available under ERISA does not adequately remedy." "156 Under this provision, Participants may sue breaching fiduciaries for traditionally available equitable remedies. ${ }^{157}$

Any person exercising "material discretion" over plan assets or administration is subject to fiduciary duties. ${ }^{158}$ Thus, individuals who make healthcare benefit decisions such as claims determinations are acting as fiduciaries and are bound by these duties. ${ }^{159}$ Each time an administrator fails to comply with the regulations, it breaches its fiduciary duties. ${ }^{160}$

Significantly, a breach of fiduciary duty cause of action does not require loss by

153. 29 U.S.C. $\S 1132(a)(3)(2006)$.

154. Colleen E. Medill, Resolving the Judicial Paradox of Equitable Relief, 39 J. MAR. L. REv. 827,829 (2006).

155. 29 U.S.C. $\S 1132(a)(3)$.

156. Varity Corp. v. Howe, 516 U.S. 489, 512 (1996).

157. Calhoon v. Trans World Airlines, Inc., 400 F.3d 593, 596 (8th Cir. 2005) ("Beneficiaries of ERISA plans may sue for breaches of fiduciary duties under 20 U.S.C. $\S 1132(a)(3)$, but the remedies they seek in such an action are limited by the language of the statute to traditionally available equitable remedies.").

158. Langbein, supra note 66 , at 1324-25.

159. See, e.g., Hill v. Blue Cross \& Blue Shield of Michigan, 409 F.3d 710, 717 (6th Cir. 2005) (noting that parties with authority to grant or deny claims are ERISA fiduciaries); LibbeyOwens-Ford Co. v. Blue Cross \& Blue Shield Mut., 902 F.2d 1031, 1035 (6th Cir. 1993) (holding that discretionary authority over claims triggered fiduciary status); H.R. REP. No. 93-1280, at 301 (1974) (Conf. Rep.), reprinted in 1974 U.S.C.C.A.N. 5038, 5081 (discussing procedures for delegating fiduciary duties, such as "allocation or delegation of duties with respect to payment of benefits"); 120 CONG. REC. 29,929 (1974) (remarks of Sen. Williams) (stating that ERISA imposes "strict fiduciary obligations upon those who exercise management or control over the assets or administration of an employee pension or welfare plan").

160. See, e.g., John Blair Comm., Inc. Profit Sharing Plan v. Telemundo Group, Inc. Profit Sharing Plan, 26 F.3d 360 (2d Cir. 1994) (finding the failure to comply with certain governing ERISA sections and the applicable Treasury regulations thereunder amounted to a breach of fiduciary duty); Larsen v. NMU Pension Plan Trust, 767 F. Supp. 554, 557 (S.D.N.Y. 1991) ("[V]iolation of the regulations is sufficient to establish a breach of fiduciary duty under $\S 404$ of ERISA ...."). 
the plaintiff; gain by the defendant is sufficient. ${ }^{161}$ That is, if a defendant "has made a profit through the violation of a duty to the plaintiff to whom he is in a fiduciary relation, he can be compelled to surrender the profit to the plaintiff although the profit was not made at the expense of the plaintiff." 162 The U.S. Securities and Exchange Commission (SEC), for example, has obtained relief in the form of equitable accounting for profits against defendants violating the securities laws.

The fiduciary duty cause of action and equitable relief, however, have proven inadequate to address ERISA regulatory non-compliance effectively. Claims for equitable accounting for profits ${ }^{94}$ have met with some success under limited circumstances-for example, a fiduciary that improperly withholds

161. Kardon v. Nat'l Gypsum, 73 F. Supp. 798, 802 (E.D. Pa. 1947) (“The plaintiff's case was established when the defendants' duty and its breach were proved. This was done by showing that the defendants were officers and directors of Western and that they disposed of the bulk of the corporate assets to an outsider, for their own benefit ... . The remedy follows, which, in this case, is an accounting to ascertain and restore ... the profits, if any."). Whether or not trust law includes a make-whole remedy for ERISA plaintiffs is the subject of considerable scholarly debate and judicial comment. For complete analysis of this issue, see Langbein, supra note 66, at 1333. However, the disgorgement remedy sidesteps this debate, because disgorgement is not intended to benefit the wronged beneficiary, but to prevent the unjust enrichment of the fiduciary. See Parke v. First Reliance Standard Life Ins. Co., 368 F.3d 999, 1008-09 (8th Cir. 2004) (explaining that the equitable accounting and unjust enrichment disgorgement remedies fit within those traditionally available in equity).

162. RESTATEMENT OF RESTITUTION §160(d), at 646 (1937); see also Langbein, supra note 66, at 1333 ("An aggrieved trust beneficiary ... may recover (1) for loss incurred, (2) for any profits that the trustee made in breach of trust, and (3) for any gains that would have accrued but for the breach.").

163. Where, for example, a defendant was found to have aided and abetted in primary violations of books and records, net capital, and reporting violations of the federal securities laws, the defendant was ordered to disgorge the profits earned by those wrongs, including commissions paid to the defendant and markups on securities. SEC v. Solow, 554 F. Supp. 2d 1356, 1363 (S.D. Fla. 2008). In such cases, the calculation need not be done with complete certainty. SEC v. Patel, 61 F.3d 137, 139-40 (2d Cir. 1995) (noting that plaintiff need only establish "a reasonable approximation of profits causally connected to the violation" to establish the amount owed); Solow, 554 F. Supp. 2d at 1363. Indeed, in analogous situations under the securities laws, once a reasonable approximation of the amount of unjust enrichment is established, the burden then shifts to the defendant to show that the approximation is unreasonable. Solow, 554 F. Supp. 2d at 1363. The risk of uncertainty in calculating the remedy falls on the defendant, whose illegal actions created the uncertainty. Id.

164. Accounting for profits is "a restitutionary remedy based upon avoiding unjust enrichment. In this sense, it reaches monies owed by a fiduciary or other wrongdoer, including profits produced by property which in equity and good conscience belonged to the plaintiff." BLACK'S LAW DictionaRY (9th ed. 2009) (quoting DAN B. DoBbS, LAW OF REMEDIES $\S 4,3(5)$, at 408 (2d ed. 1993)). 
benefits can be held liable for interest on the withheld money on an unjust enrichment theory. ${ }^{165}$ But while the "catch-all" provision cause of action is an avenue against a plan administrator or ultimate payor's unjust enrichment through improper claims processing, this cause of action is difficult to prove and often unfruitful. ${ }^{166}$ Any individual instance of non-compliance (such as a failure to communicate appeal rights or the basis for a denial) does not result in significant unjust enrichment to the defendant beyond the amount of the denied claim. In addition, this cause of action does not capture the most significant unjust enrichment of defendants resulting from regulatory non-compliance: The cost savings where claims are improperly denied and not appealed. The unjust enrichment of Payors is more difficult to quantify in an ERISA breach of fiduciary duty claim than in other areas of the law, such as securities law, in which the wrongdoing more often results in a greater single, traceable profit.

Empirical research has found a correlation between higher Payor denial rates and profits. ${ }^{167}$ And under trust law, the benefits gained in breach of a trust are subject to equitable disgorgement. When the denials conflict with the terms of ERISA plans and the Payors' or plan administrators' fiduciary duties to Participants, the unpaid monies should be recoverable, not as compensation to Participants, but as equitable disgorgement due to unjust enrichment.

Here again, trust law proves inadequate to address the particular needs of ERISA plans, because its application has led only to confusing and uncertain results. ERISA's legislative history makes clear that the courts are expected to develop the federal common law of ERISA to develop the "appropriate equitable relief" set out in $\$ 1132(\mathrm{a})(3)(\mathrm{B})$ and other areas of ERISA that were not explicitly drawn. ${ }^{168}$ But this section has not led to any clear remedies, and uncertainty still exists as to exactly what relief this provision can provide.

Where a single cause of action is too minimal to bring alone, but the wrong being addressed appears to occur pervasively, the class action mechanism may

165. Parke v. First Reliance Standard Life Ins. Co., 368 F.3d 999, 1005-09, (8th Cir. 2004) (" $[\mathrm{A}] \mathrm{n}$ award of interest on wrongfully delayed benefits remains permissible $\ldots$ as a remedy for a breach of fiduciary duty to a beneficiary."); Dunnigan v. Metro. Life Ins. Co., 214 F.R.D. 125, 13435 (S.D.N.Y. 2003) (noting that interest on wrongfully withheld benefits is available under ERISA because it fits within the relief "typically available in equity").

166. See, e.g., Knieriem v. Group Health Plan, Inc., 434 F.3d 1058, 1064 (8th Cir. 2006) (dismissing action under 29 U.S.C. $\$ 1132(a)(3)(B)$ for accounting for profits for alleged wrongful benefits denial).

167. Greenberg et al., supra note 43, at 633 (finding a "strong positive correlation" between net profit margin and the adjusted odds that the plan would discount the cost of a day's stay in the hospital).

168. Senator Jacob Javits, for example, is often cited as noting that the federal courts were to develop "a body of Federal substantive law ... to deal with issues involving rights and obligations under private welfare and pension plans." 120 CONG. REC. 29,942 (1974). 
provide an avenue for recovery. But class actions have not been a panacea for ERISA non-compliance. Participant classes frequently founder on requirements such as commonality of legal and factual issues, and the causal link between the alleged wrongdoing and resulting damages can be too remote.

For example, where proposed Participant classes have brought lawsuits for interest on denied or delayed claims, courts have found that individualized analysis is required and class action treatment is unsuitable. ${ }^{169}$ That is, unless the class meets the requirements under the Federal Rules of Procedure to be brought as a class action, all the parties must be joined and the lawsuit cannot go forward as a class action. ${ }^{170}$ Some narrowly drawn classes seeking injunctive relief for specific, plan-wide improper treatment of claims are permitted to go forward. ${ }^{171}$ But in order for the class of Participants to have a significant chance of certification, the class must be carefully drawn, the remedy sought must be distinct from the claim for benefits, and the equitable remedy must be traceable to the alleged harm. ${ }^{172}$ The class action vehicle is therefore an uncertain and ungainly tool against most instances of regulatory non-compliance.

Thus, regulatory non-compliance in the processing of healthcare claims for the most part results in no remedy at all. The most flagrant examples may result in a procedural action such as remand for further review, but regulatory noncompliance for the most part leads to no substantive remedy. Given the deferential standard of review applied to plan administrators' decisions and the

169. See, e.g., Miner v. Empire Blue Cross/Blue Shield, 2001 WL 96524 (S.D.N.Y. Feb. 5, 2001) (holding that claims for interest on delayed benefit payments may not be brought as a class action); Dunnigan v. Metro. Life Ins. Co., 99 F. Supp. 2d 307, 325-26 (S.D.N.Y. 2000); Holmes v. Pension Plan of Bethlehem Steel Corp., No. Civ. A 98-CV-1241, 1999 WL 554591, at *7 (E.D. Pa. June 30, 1999), aff'd, 213 F.3d 124 (3d Cir. 2000) (“[C]ourts are still required to make individual assessments of each claim, examine the individual facts behind each claim, balance the equities, and determine that a benefit payment was improperly delayed.").

170. FED. R. CIV. P. 23(a) ("One or more members of a class may sue or be sued as representative parties on behalf of all class members only if: (1) the class is so numerous that joinder of all members is impracticable, (2) there are questions of law or fact common to the class, (3) the claims or defenses of the representative parties are typical of the claims or defenses of the class, and (4) the representative parties will fairly and adequately protect the interests of the class.").

171. See, e.g., Hill v. Blue Cross \& Blue Shield of Michigan, 409 F.3d 710, 718 (6th Cir. 2005 ) (reversing dismissal of fiduciary-duty claims). The court wrote, "Only injunctive relief of the type available under $\S 1132$ (a)(3) will provide the complete relief sought by Plaintiffs by requiring BCBSM to alter the manner in which it administers all the Programs' claims for emergencymedical-treatment expenses." Id.

172. See, e.g., id.; Parke v. First Reliance Standard Life Ins. Co., 368 F.3d 999, 1004 (8th Cir. 2004) (affirming denial of certification of putative Participant class seeking injunctive relief against insurer's denial or suspension of disability benefits without evidence that disability no longer existed; disability determination was too individual for class action). 
financial conflicts inherent in the process, the available remedies for regulatory non-compliance are simply inadequate to protect Participants' access to their promised benefits.

\section{THE PRESUMED HARM APPROACH TO ENFORCEMENT OF ClAIMS PROCESSING REGULATIONS}

If compliance with claims regulations is to be attractive, non-compliance must be financially unattractive. ${ }^{173}$ Currently, financial incentives weigh heavily in favor of non-compliance, because non-compliance generally results in no substantive remedy. Two possible approaches to enforcement of claims regulations would disincentivize non-compliance with claims processing regulations. The discretionary attorney's fee remedy could be used more aggressively to penalize regulatory non-compliance, as a minority of courts is already doing. In the longer term, ERISA's enforcement provision and regulations could explicitly adopt the presumed-harm approach of consumer finance statutes.

\section{A. Recognizing the Harm: Attorney's Fees as Deterrent to Regulatory Non- compliance}

Where a defendant fails to comply with claims regulations, some courts award attorney's fees, even if the defendant cures the non-compliance during litigation or the claim is remanded to the plan administrator for further review. ${ }^{174}$

173. In Schoedinger v. United Healthcare, No. 4:04-cv-664 SNL, 2006 WL 3803935, at *8 (E.D. Mo. Nov. 6, 2006), the court awarded attorney's fees to a healthcare provider who had faced repeated delays and denials of his claims. The court noted:

Whether it be purposeful or negligent, insurance companies regularly reduce and deny claims without cause, thereby increasing the cost of healthcare to providers and patients alike. If it became cost prohibitive for insurance companies to engage in that behavior, it would incentivize more accurate claims administration and processing in the future.

Id.

174. See, e.g., Mizzell v. Provident Life \& Accident Ins. Co., 32 Fed. App'x 352, 355 (9th Cir. 2002) (affirming award of attorney's fees where court remanded to plan administrator for full and fair review of denial); Finks v. Life Ins. Co. of N. Am., No 08-1272 (ESH)(AK), 2009 WL 2230899, at *6 (D.D.C. July 24, 2009) (awarding attorney's fees where Payor paid claims during litigation); Colby v. Assurant Emp. Benefits, 635 F. Supp. $2 d 88$ (D. Mass. 2009) (awarding fees upon remand to plan administrator for review); Moskalski v. Bayer Corp., No. 2:06-cv-568, 2008 WL 2096892, at*1-2 (W.D. Pa. May 16, 2008) (awarding attorney's fees on remand to plan administrator, where administrator's decision "lacked sufficient foundation" and court sought to provided a financial incentive for Payors "to properly support [their] conclusions at the administrative level"); Schoedinger, 2006 WL 3803935, at *7 (awarding attorney's fees where defendant paid some claims during litigation and agreed on other amounts due). 
An award of attorney's fees acts as some deterrent to plan administrators who would delay or deny claims improperly, and this approach can be more widely adopted in order to encourage compliance with claims processing regulations.

In ERISA cases, courts have discretion to award attorney's fees to either party. ${ }^{175}$ A court may award attorney's fees to either party if the party receives "some degree of success on [the] merits." "176 An award of ERISA attorney's fees generally begins with analysis of the following factors:

(1) the degree of opposing parties' culpability or bad faith; (2) ability of opposing parties to satisfy an award of attorneys' fees; (3) whether an award of attorneys' fees against the opposing parties would deter other persons acting under similar circumstances; (4) whether the parties requesting attorneys' fees sought to benefit all participants and beneficiaries of an ERISA plan or to resolve a significant legal question regarding ERISA itself; and (5) the relative merits of the parties' positions. 17

The factors are not statutory, but are flexible guidelines that courts have used to guide this discretionary analysis. ${ }^{178}$

When a court finds that a plan administrator has not complied with claims regulations and the court remands the claim to the plan administrator, a plaintiff may well receive no attorney's fee award. ${ }^{179}$ As courts address each of the five attorney's fee factors, non-compliance with claims processing regulations often does not amount to the "culpability or bad faith" addressed in the first attorney's fee factor. ${ }^{180}$ And, where claims processing is concerned, a deterrent effect on

175. 29 U.S.C. $\S 1132(\mathrm{~g})(1)(2006)$ (providing that in any ERISA action "by a participant, beneficiary, or fiduciary, the court in its discretion may allow a reasonable attorney's fee and costs of action to either party").

176. Hardt v. Reliance Standard Life Ins. Co., 130 S. Ct. 2149 (2010) (citing Ruckelshaus v. Sierra Club, 463 U.S. 680, 694 (1983)).

177. Id. (quoting Quesinberry v. Life Ins. Co. of N. Am., 987 F.2d 1017, 1029 (4th Cir. 1993)).

178. Foltice v. Guardsman Prods., Inc., 98 F.3d 933, 937 (6th Cir. 1996).

179. See, e.g., Graham v. Hartford Life \& Accident Ins. Co., 501 F.3d 1153, 1162 (10th Cir. 2007) (holding that attorney's fee issue was not ripe until after plan administrator's review on remand); Quinn v. Blue Cross \& Blue Shield Ass'n, 161 F.3d 472, 479 (7th Cir. 1998) (affirming lower court's holding that defendant did not complete a proper vocational review and that denial of disability benefits was arbitrary and capricious but reversing fee award because defendant's decision was not "totally lacking in justification"); St. Joseph's Hosp. v. Carl Klemm, Inc., 459 F. Supp. 2d 824, 834 (W.D. Wis. 2006) (denying motion for attorney's fees, based on the absence of evidence that defendant was "simply out to harass" plan participant).

180. See, e.g., Kansas v. Titus, 452 F. Supp. 2d 1136, 1153 (D. Kan. 2006) (holding that notification did not comply with claims regulations, but declining to find defendant "culpable" and awarding no fees); Towner v. CIGNA Life Ins., 419 F. Supp. 2d 172, 186 (D. Conn. 2006) (finding that defendant's claims processing did not comply with regulations, but finding no culpability and 
other defendants is not necessarily cited in weighing the attorney's fee factors. ${ }^{181}$ Moreover, in addressing the fourth factor, value to other plan participants, most courts understand an ERISA claim dispute as an individual matter, such that the lawsuit has no value to other participants. ${ }^{182}$

A few courts, however, are leading the way in a broader, more consumeroriented approach. These courts are using an award of attorney's fees to serve as a disincentive to improperly process claims or deny or delay claims until a lawsuit is filed. ${ }^{183}$ Broadening the usual constricted view of ERISA remedies, these courts note the present disincentives to adhere to claims processing procedures, and they award fees against plan administrators who refuse to follow the claims processing regulations. ${ }^{184}$ These courts look to the incentives created

awarding no fees). But see Perrin v. Hartford Life Ins. Co., No. 06-182-JBC, 2008 WL 2705451, at *3 (E.D. Ky. July 7, 2008) ("[D]efendant was highly culpable" based on "disregard for objective medical evidence"); Elliott v. Metro. Life Ins. Co., No. 04-174-DLB, 2007 WL 1558519, at *3 (E.D. Ky. May 29, 2007) (finding that defendant was culpable for purposes of fee award, based on disregard of treating physicians and other factors in disability case); Plummer v. Hartford Life Ins. Co., No. C-3-06-094, 2007 WL 838926 (S.D. Ohio Mar. 15, 2007) (finding defendant "at best, highly culpable" due to its reliance on at least three flawed medical opinions and misstatements of law and fact in litigation); Crider v. Highmark Life Ins. Co., No. 1:05-cv-660, 2006 WL 6157958, at *2 (W.D. Mich. Nov. 21, 2006) (finding defendant "highly culpable" without addressing subjective state of mind, but based on "gross error" in terminating benefits).

181. St. Joseph's Hosp., 459 F. Supp. $2 d$ at 834 (holding that plaintiff "was not provided an opportunity for full and fair review" and awarding no attorney's fees); Towner, 419 F. Supp. 2d at 186 (D. Conn. 2006) (finding that defendant's claims processing did not comply with regulations but finding no behavior that warranted deterrence and awarding no fees).

182. See, e.g, Foltice, 98 F.3d at 937 (finding that where the lawsuit created no common fund, the fourth factor weighed in favor of defendant); McDonald v. Western-Southern Life Ins. Co., No. C2-98-414, 2002 WL 484623, at *4 (S.D. Ohio Feb. 20, 2002) (holding that plaintiff sought his own benefits and therefore did not confer any value on other participants).

183. One court explained succinctly the need for an attomey's fee deterrent against mishandling of claims, particularly where the Payor both decides and funds claims:

[T]here is evidence in the record to support a conclusion that the insurance company engaged in a campaign of evaluation and re-evaluation of plaintiff's claim, in a single-minded effort to document reasons for denial. From a purely economic point of view, this is rational behavior. From a fiduciary point of view, it is not. If the only consequence of an arbitrary denial of benefits is the chance of being sued and a possibility of reinstatement of benefits at some future date, insurance companies with this strong conflict of interest will have little incentive to adhere to their fiduciary obligations.

Crider v. Highmark Life Ins. Co., 1:05-cv-660, 2006 WL 6157958, at *2 (W.D. Mich. Nov. 21, 2006) (awarding attorney's fees against defendant that arbitrarily terminated benefits).

184. Crider, 2006 WL 6157958, at *3; see also Beauvais v. Citizens Fin. Group Inc., 418 F. Supp. 2d 22, 33 (D.R.I. 2006) (awarding attorney's fees where defendant discontinued benefits based on plaintiff's failure to produce records that the defendant had never even requested); Black 
by the lack of ERISA remedies and the comparatively small number of benefit regulation violations that are actually brought to court. As one such court observed:

[A]n award of attorney's fees ... . is an important deterrent measure: first, because of the limited remedy available to ERISA plaintiffs . . insurers should be dissuaded from prematurely suspending benefits with the hope that some claimants will not sue; and second, because an award of attorney's fees ensures that attorneys continue to take on ERISA cases in which the potential monetary award may be limited. ${ }^{185}$

These courts analyze the ERISA attorney's fee factors differently and with ERISA's overall context in mind. Confronted directly with plan administrators' recalcitrance, or even a cavalier attitude toward ERISA regulations, the consumer-oriented courts are finding fee awards appropriate under a broader view of the five factors. ${ }^{186}$

In one such case, a plan administrator denied a long-term disability claim until the Participant filed suit. ${ }^{187}$ During the course of the litigation, the administrator paid the claim. ${ }^{188}$ The Participant pressed the lawsuit, and the court awarded interest on the disability benefits and then analyzed the factors

v. Unum Life Ins. Co., 324 F. Supp. 2d 206, 219 (D. Me. 2004) (citing defendant's "low level of care to avoid improper denial of claims, at great human expense").

185. Giroux v. Fortis Benefits Ins. Co., 353 F. Supp. 2d 45, 54 (D. Me. 2005) (quoting Black v. Unum Life Ins. Co., 324 F. Supp. 2d 206, 219 (D. Me. 2004)); see also Curtin v. Unum Life Ins. Co., 298 F. Supp. 2d 149, 159 (D. Me. 2004) (awarding attorney's fees where defendant took insufficient care to avoid improper claim denials and noting the "limited remedies available under ERISA for plaintiffs such as [plaintiff] Ms. Curtin").

186. See, e.g., Perrin v. Hartford Life Ins. Co., No. 06-182-JBC, 2008 WL 2705451, at *4 (E.D. Ky. July 7, 2008) (awarding fees in order to deter other defendants from mishandling claims); Becker v. Weinberg Grp., Inc., 554 F. Supp. 2d 9, 18 (D.D.C. 2008) ("If [defendants] understood that clearly erroneous actions taken by them ... . would be subject to attorneys' fees, that might well deter them from engaging in such conduct."); Elliott v. Metro. Life Ins. Co., No. 04-174-DLB, 2007 WL 1558519, at *3 (E.D. Ky. May 29, 2007) ("[T] here is also something to be said for the heightened deterrent effect resulting from a fee award. Companies would likely take a much closer look at denial decisions, and the presentation of that decision, if forced to take into account the possibility that fees will be awarded upon remand."); Risteen v. Youth for Understanding, Inc., No. Civ.A. 02-0709(JDB), 2003 WL 22011766, at *4 (D.D.C. Aug. 19, 2003) (“Awarding attorney's fees to [Plaintiff] will provide future employers added incentive to comply with ERISA . . regulations, and encourage employers to resolve such disputes sooner rather than later, before attorney's fees mount.").

187. Finks v. Life Ins. Co. of N. Am., No. 08-1272 (ESH)(AK), 2009 WL 2230899, at *6-8 (D.D.C. July 24, 2009) (awarding attorney's fees where Payor paid claims during litigation).

188. Id. at *1. 
governing attorney's fee awards under a broad, remedial lens. ${ }^{189}$ In considering the deterrent effect of a fee award, the court noted case law explaining that an attorney's fee award should deter violations of ERISA as well as unnecessary prolongation or unjust resolution of claims. ${ }^{190}$ The court also noted the plan administrator's "cavalier attitude" toward ERISA's regulatory deadlines. 19

While many courts still interpret ERISA's damage provisions narrowly, the broader view of ERISA attorney's fees for regulatory violations appears to be gaining ground in the face of the scant remedies otherwise available. ${ }^{192}$ The attorney's fee solution is, however, far from a panacea. Attorney's fees are not available for administrative action without litigation, so the availability of attorney's fees is no detriment at all to administrators who would refuse to pay claims initially and then pay on appeal or settle the claim as soon as litigation is initiated. ${ }^{193}$ Furthermore, while more consistent fee awards may act as some deterrent to non-compliance with claims regulations, the attorney's fee provision remains discretionary and therefore uncertain. The attorney's fee provision of ERISA amounts to some financial disincentive against ignoring claims processing regulations. But given the minute percentage of denied claims that proceed through the internal appeal and litigation processes to final judgment, the

189. Finks, 2009 WL 2230899.

190. Id. at *2 (citing Eddy v. Colonial Life Ins. Co. of Am., 59 F.3d 201, 206 (D.C. Cir. 1995)).

191. Id. at *4 (noting with disapproval Payor's insistence that it had not backdated documents so as to appear to be in compliance with regulatory deadlines, because it had no incentive to do so-violation of the regulatory deadline would likely have no effect on Payor anyway). In addition, the court considered the benefit that this lawsuit would confer on others. The court found that the plaintiff's ability to enforce the terms of an insurance contract and perhaps dissuade insurance companies from denying benefits until a lawsuit is filed was a benefit to other plan participants and therefore a factor in the analysis. Instead of weighing in favor of the defendant as in the usual case, this factor, the court found, weighed equally in favor of the plaintiff and defendant. $I d$. at $* 5$.

192. See, e.g., Gatlin v. Nat'l Healthcare Corp., 16 F. App'x 283, 290 (6th Cir. 2001) (“[A] stiffer penalty encourages plan administrators to alter their behavior with respect to employee appeals. ..."); Perrin v. Hartford Life Ins. Co., No. 06-182-JBC, 2008 WL 2705451, at *4 (E.D. Ky. July 7, 2008) ("[T] denial decisions if it is faced with more than the prospect of merely reinstating benefits."); Elliott v. Metro. Life Ins. Co., No. 04-174-DLB, 2007 WL 1558519, at *3 (E.D. Ky. May 29, 2007) ("Companies would likely take a much closer look at denial decisions, and the presentation of that decision, if forced to take into account the possibility that fees will be awarded."); Powell v. Premier Mfg. Support Servs., Inc., No. Civ.A. 01-05-0012, 2006 WL 1529470, at *10 (M.D. Tenn. June 1, 2006) ("A fee award serves as a deterrent to conclusory statements that are devoid of specific and fact-supported reasons for denial of benefits.").

193. Parke v. First Reliance Standard Life Ins. Co., 368 F.3d 999, 1011 (8th Cir. 2004) (joining "the Second, Fourth, Sixth, and Ninth Circuits in holding that the term 'any action' in 29 U.S.C. $§ 1132(\mathrm{~g})(1)$ does not extend to pre-litigation administrative proceedings”). 
chance of an attorney's fee award being assessed against a plan administrator remains slim.

\section{B. Presuming the Harm: A Regulatory Solution to Claims Processing Non- compliance}

Consistent enforcement of ERISA's regulations calls for an approach akin to that of consumer financial protections such as the Truth in Lending Act (TILA). ${ }^{194}$ TILA's Regulation $Z,{ }^{195}$ for example, sets out requirements for disclosure of consumer finance terms and provides penalties for non-compliance regardless of actual harm. Similar enforcement of claims regulations under ERISA would lend consistency to the enforcement process by providing a clear incentive for administrators to comply with claims processing regulations.

A regulatory solution to the problem of claims processing begins by recognizing that trust law requires supplementation in order to fulfill ERISA's purpose: the provision of contracted benefits. At present, the struggle to find essentially regulatory solutions within trust law is undermining the availability of benefits. Lawsuits for non-compliance with claims processing regulations are increasing in complexity as courts vainly sift through arcane trust law in a quest for sensible solutions. ${ }^{196}$ Instead, a consumer-oriented regulatory solution would provide the clarity and predictability that those seeking healthcare should have.

\section{Claims Processing Compliance Through a Presumed-Harm Approach Akin to that of the Truth in Lending Laws}

The DOL has issued additional language strengthening claims procedure regulation. $^{197}$ In order to be effective, though, the regulations must carry significant, clear consequences for non-compliance. The enforcement provisions of TILA and its Regulation Z exemplify the kind of provisions that could, if adopted as part of ERISA's enforcement provisions and regulations, increase compliance with claims processing regulations.

TILA concerns consumer credit, requiring certain disclosures from those who extend credit. ${ }^{198}$ The law was written to address the concern that Americans were uninformed in taking on debt and needed transparency regarding credit terms. ${ }^{199}$ TILA's goal was to require disclosures of finance charges and related

194. 15 U.S.C. $\S 1601(2006)$.

195. 12 C.F.R. $\S 226$ (2010).

196. See, e.g., Mertens v. Hewitt Assocs., 508 U.S. 248, 262 (1993) (noting that ERISA is "an enormously complex and detailed statute" and examining trust law at the time of the divided bench to determine appropriate remedies in ERISA cases).

197. See discussion supra Section II.A.

198. 15 U.S.C. $\S 1601$ (a); Mourning v. Family Publ'ns Serv., Inc., 411 U.S. 356, 363 (1973).

199. Clement v. Am. Honda Fin. Corp., 145 F. Supp. 2d 206, 210 (D. Conn. 2001) (noting that 
information so that consumers could find the best terms available to them; TILA also aimed to protect consumers against inaccurate credit billing. ${ }^{200}$

Although ERISA and TILA concern different subjects, these two laws have much in common. Like ERISA, TILA was enacted to address a problem that affected the finances of individuals. ERISA and TILA both regulate an area of law that affects millions of consumer transactions. ${ }^{201}$ Both statutes sought to bring uniformity to their respective areas. ${ }^{202}$ Moreover, the legislative histories of both ERISA and TILA show an overriding concern for communication and clarity. $^{203}$

In the case of ERISA, as explained above, the initial concern was solvency of pension plans; only later did it come to play a significant role in the regulation of healthcare coverage. ${ }^{204}$ As a result, ERISA affects not just the finances but also the health of millions of individuals. While both TILA and ERISA concern matters that affect families' lives, TILA holds defendants to exacting standards and enforcement requires no showing of individual harm-features that are absent from the enforcement of ERISA's claims processing regulations.

Where enforcement is concerned, the two statutes and their regulations are quite different. $^{205}$ TILA contains specific statutory remedies for specific

disclosures required by TILA "are intended to provide, especially to the inexperienced and uninformed consumer, a way to avoid 'the possibility of deception, misinformation, or at least an obliviousness to the trust costs' of a credit transaction") (citing Griggs v. Provident Consumer Discount Co., 503 F. Supp. 246, 250 (E.D. Pa. 1980)).

200. Cf. Mourning, 411 U.S. at 363 (explaining that TILA was prompted by a finding that consumers were "remarkably ignorant of the nature of their credit obligations").

201. Matthew A. Edwards, Empirical and Behavioral Critiques of Mandatory Disclosure: Socio-Economics and the Quest for Truth in Lending, 14 CORNELl J.L. \& PUB. POL'Y 199, 203 (2005) (noting that TILA applies to virtually every consumer credit transaction, including mortgages, car loans, and credit card purchases).

202. Ian S. McCrea, Truth in Lending, A Discussion of Koons Buick Pontiac GMC, Inc. v. Bradley Nigh, 32 S.U. L. REV. 269, 269 (2005) (explaining that TILA sought to "provide economic stabilization among credit lending institutions" and "create uniform regulations among the states").

203. Congress's purpose in enacting the ERISA disclosure provisions was partly to ensure that "the individual participant knows exactly where he stands with respect to the plan . . ." H. R. REP. No. 93-533, at 11 (1973); see also 15 U.S.C. $\$ 1601$ (a) (2006) ("The informed use of credit results from an awareness of the cost thereof by consumers. It is the purpose of this subchapter to assure a meaningful disclosure of credit terms so that the consumer will be able to compare more readily the various credit terms available to him and avoid the uninformed use of credit ....").

204. WOOTEN, supra note 11, at 5, 281.

205. Edwards, supra note 201, at 212 ("Although Congress delegated rulemaking responsibility for implementing TILA to the Board of Governors of the Federal Reserve System, enforcement authority for the Act was divided among nine Federal agencies, led by the Federal Trade Commission"). With regard to ERISA, on the other hand, the Secretary of Labor has general regulatory authority, 29 U.S.C. $\S 1135$, and can initial legal proceedings to enforce ERISA. 29 
violations. ${ }^{206}$ First, a TILA plaintiff has a cause of action to recover any actual damage sustained by the plaintiff. ${ }^{207}$ Second, the plaintiff can recover statutory damages of twice the amount of the finance charge in connection with the transaction, except that the award cannot be less than $\$ 100$ or greater than $\$ 1,000$. $^{208}$ Third, a court has discretion to award statutory damages in the amount of the lesser of $\$ 500,000$ or one percent of the defendant's net worth in a class action. $^{209}$ The statute also provides for criminal penalties for willful and knowing violations. $^{210}$

Significantly, the award of statutory damages results from the violation of the statute, rather than any particular effect upon the plaintiff. The plaintiff need not show any specific harm flowing from the non-compliance; lenders are generally held strictly liable for inaccuracies, even if there is no showing that the inaccuracies are misleading. ${ }^{211}$ In one case, for example, the plaintiffs did not speak or read English and so could not have read the disclosures had they been given. But statutory damages were awarded based on an objective evaluation of the disclosures' compliance with the statute. ${ }^{212}$

While TILA imposes strict liability on lenders, it also contains a "bona fide error" defense for technical mistakes or mistakes made despite "the maintenance of procedures reasonably adapted to avoid any such error."213 A defendant can avoid liability by showing an error of calculation or omission occurred, and that the defendant employed procedures, such as accuracy reviews, to ensure that mistakes were not made. ${ }^{2 \sqrt{4}}$

By most accounts, TILA is effective in encouraging regulatory compliance and straightforward enforcement. Indeed, it has been called "a tremendous success." 215 The "modest automatic statutory penalty" described above is

U.S.C. $\S 1132(\mathrm{a})(5)$. The Department of Treasury regulates ERISA plans claiming tax-exempt status. Id. $\S 1202$ (b).

206. 15 U.S.C. $\S 1640(a)(2006)$.

207. $\$ 1640(a)(1)$.

208. $\$ 1640(\mathrm{a})(2)(\mathrm{A})$.

209. $\S 1640(\mathrm{a})(2)(\mathrm{B})$.

210. $\S 1611$.

211. Smith v. Cash Store Mgmt., Inc., 195 F.3d 325, 328 (7th Cir. 1999).

212. Zamarippa v. Cy's Car Sales, 674 F.2d 877, 879 (11th Cir. 1982) (holding that where a title transfer fee was included within the cash price of a vehicle rather than within the cost of credit as required by TILA, statutory damages were appropriate "regardless of the district court's belief that no actual damages resulted or that the violation is de minimus"); see also Sosa v. Fite, 498 F.2d 114, 116 (5th Cir. 1974).

213. 15 U.S.C. $\S 1640(\mathrm{c})$.

214. Abel v. Knickerbocker Realty Co., 846 F. Supp. 445, 449 (D. Md. 1994) (declining to apply bona fide error defense where lender's failure to include origination fee in finance charge was accidental but no procedures were in place to ensure accuracy).

215. Russell v. Fidelity Consumer Discount Co. (In re Russell), 72 B.R. 855, 862 (Bankr. E.D. 
particularly effective, one court notes, where "actual damages were perhaps nonexistent and [are], in any event, almost impossible to prove." ${ }^{216}$ As previously described, the harm that results when administrators fail to comply with ERISA's claims processing regulations is similarly difficult to prove, hard to quantify, and in some individual cases non-existent.

Like TILA, ERISA contains statutory penalty provisions related to healthcare claims. ERISA provides for a $\$ 110$ per day penalty for each day following the expiration of thirty days following a Participant's request for a Summary Plan Description ${ }^{217}$; ERISA also provides statutory penalties for failure to provide appropriate COBRA notices. ${ }^{218}$ But with regard to disclosure of other required information, such as the basis for a claim denial or the Participant's right to appeal, the regulations do not provide any specific remedy. Given the likelihood of Participant attrition during the appeal and litigation process, then, the incentive is to skimp on communications that would focus Participants on particular reasons for claim denials or that would provide Participants with information about how advance their appeals. ${ }^{219}$

If reforms were enacted such that certain violations of claims processing regulations led to specific monetary penalties, all parties would have greater certainty as to their expectations with regard to the claims processing procedures and outcomes. The important concerns of uniformity and predictability-for Participants, Payors, and their administrators-would equally be served by strict liability for departures from the claims processing regulations. Participants should be able to expect that the regulations applicable to healthcare claims are followed - that, for example, a review intended to be "full and fair" and completed within a certain period of time actually will be so. ${ }^{220}$

Pa. 1987); Regulatory Restructuring: Enhancing Consumer Financial Products Regulation: Hearing Before the H. Comm. on Financial Services, 111 th Cong. 142 (2009) (statement of Travis Plunkett, Legislative Director, Consumers Union) ("Private enforcement is the norm and has worked well as a complement to public enforcement in the vast majority of the consumer statutes that will be consolidated under the CFPA, including TILA . . . Conversely, the statutes that lack private enforcement mechanisms are notable for the lack of compliance.").

216. 72 B.R. at 862 .

217. 29 U.S.C. $\$ 1132(\mathrm{c})(1)(\mathrm{A})(2006)$.

218. Id.

219. See, e.g., U.S. Gov't Accountability Office, GAO-11-268, Private Health INSURANCE: DATA ON APPLICATION AND COVERAGE DENIALS (2011), available at http://www.gao.gov/new.items/d1 1268.pdf ("[D]enials are often coded for the most general reason even though the denial may be for a more specific reason.").

220. Some aspects of the claims process are more susceptible to strict application of penalties than others. For example, the presence or absence of required language in a notice to participants would be more straightforward to assess than whether a plan administrator conducted the required "full and fair" review. However, any lack of clarity in the standard for compliance suggests not that enforcement should be lessened, but that the standard lacks the necessary specificity. At present, 
Uniformity and predictability are important to plan administrators and Payors too, as liabilities are difficult to manage if plans are subject to a variety of interpretations. ${ }^{221}$ The Court's solution to the problem of uniformity is for the plan administrator's decision on claims to be given maximum deference, so that Payors and their administrators can plan their affairs and not be subject to varying interpretations of the plan by different federal courts. ${ }^{222}$ But given this adherence to deferential review-even where the plan administrator's initial interpretation of a plan is completely mistaken-accurate claims processing is even more important. With penalties that would ensure a firm commitment to claims processing regulations, administrators would be more likely to have uniform claims processing procedures in place, and therefore to avoid inaccurate claim denials. Similarly, on appeal, administrators would be more likely to conduct the required full and fair review of denied claims, so that any improperly denied claims could be granted administratively, instead of in litigation, in keeping with ERISA's goals. ${ }^{223}$ Thus, clear monetary penalties for claims procedure non-compliance would increase uniformity and predictability.

Set out below are the same examples of problematic health insurer practices that are described in Section II.B above. Currently, these practices go all but unremedied under ERISA. A reformed TILA-like regime would provide a specific, monetary remedy for the following breaches of claims regulations, with the same kind of bona fide error defense that TILA provides:

- Denying a claim incorrectly upon initial filing, then, if the Participant appeals, paying the claim upon first-level internal appeal. Under a more effective enforcement regime, the administrator could be subject to a modest penalty, geared to the dollar amount of the claim; as with TILA, administrators could avoid the penalty completely through a "bona fide error" defense which demonstrates that procedures are in place to avoid errors.

- Denying certain types of claims incorrectly upon initial filing, then paying them during litigation. Similar to the example above, the administrator could be subject to a modest penalty, but increased by a multiplier to reflect the Participant's additional time and trouble, so that it is larger than the penalty for paying the claim

any risk of confusion or lack of clarity in the regulations falls on Participants, because Payors can maneuver at will within any areas of uncertainty.

221. Health, Educ. \& Hum. Servs. Div., supra note 63, at 25 (noting that the Department of Labor and others favor stronger remedies for non-compliance with the claims process, so that "upstream" compliance is improved).

222. Conkright v. Frommert, 130 S. Ct. 1640,1650 (2010) (noting that the creation of ad hoc exceptions to deferential review would cause uniformity problems in plan interpretation).

223. Id. at 1649 (noting that ERISA encourages claims to be handled at the administrative level rather than through litigation). 
during internal appeal.

- Paying claims outside the regulatory deadlines. Prompt pay laws enacted by fourteen state governments require interest plus penalties to be paid on late claims. ${ }^{224}$ Federal laws should also provide that administrators pay interest on improperly delayed claims.

- Failing to communicate the basis for the claim denial or the Participant's right to appeal. Without a clear understanding for the basis of a denial or the manner in which to appeal, the Participant lacks the tools to pursue contracted benefits. Here too, the penalty could be geared to the dollar amount of the claim at issue, with a bona fide error defense available.

A regulatory regime such as this would support ERISA's original goal of ensuring contracted benefits. Congress intended ERISA to provide broad remedies to redress violations and to remove procedural and jurisdictional obstacles to enforcement. ${ }^{225}$ While ERISA was based on trust law, Congress also saw fit to add statutory penalties where necessary to advance specific, important goals. ${ }^{226}$ Congress imported trust law in order to provide an enforcement framework and impose fiduciary duties on plan decision-makers, but Congress predicted that the federal courts would develop a particular federal common law that would suit ERISA's goals and purposes. ${ }^{227}$ Instead of a specialized federal common law, however, current ERISA law has developed into an "unjust and increasingly tangled ... regime" that often amounts to a "regulatory vacuum.",228

For this reason, many courts have called for ERISA reform; some urge the Court to revisit its interpretation of equitable remedies available under ERISA. ${ }^{229}$ But increasingly, courts and commentators argue that trust law-based on the principles of fiduciary duty ${ }^{230}$ that are simply a fiction under ERISA-does not

224. Monica E. Nussbaum, Prompt Pay Statutes Should Be Interpreted To Grant Providers a Private Right of Action To Seek Enforcement Against Payors, 15 HeAlth MATRIX 205, 230 (2005) (setting out and comparing fines and penalties contained in states' prompt pay laws).

225. S. REP. No. 93-127, (1974), reprinted in 1974 U.S.C.C.A.N. 4639, 4871.

226. 29 U.S.C. $\S 1132$ (c) (2006) (setting out penalties for failing to meet certain disclosure and notice requirements regarding COBRA, annual reports, summary plan descriptions, and other notice provisions).

227. WOOTEN, supra note 11 , at 282 (discussing Senator Jacob Javits's concern over the expansion of preemption and the absence of any replacement ERISA action).

228. See, e.g., Aetna Health v. Davila, 542 U.S. 200, 222-23 (2004) (Ginsburg, J., concurring) (quoting DiFelice v. Aetna U.S. Healthcare, 346 F.3d 442, 453, 457 (3d Cir. 2003) (Becker, J., concurring)).

229. See id. at 223 (urging Congress or the Court to revisit the issue of the availability of consequential damages against breaching fiduciaries).

230. Under the exclusive benefit rule, ERISA fiduciaries must discharge their duties with 
fit the goals of Congress when it enacted ERISA. The time for firm and precise claims processing and enforcement reform has come.

Of course, no one would relish increased complexity in regulatory compliance or enforcement. But if the compliance and enforcement experience of the TILA is any indication, specific, direct penalties for non-compliance with claims processing regulations should lead to increased compliance rather than increased complexity. ${ }^{231}$ Greater compliance favors Participants, but in many ways advances the interests of Payors and their administrators as well.

\section{A Separate Peace: Piecemeal and Inconsistent Private Reform Through Provider Class Actions}

In the absence of effective claims processing regulations, healthcare providers are accomplishing a measure of private reform through class actions. ${ }^{232}$ These efforts only underscore the need for regulatory reform, however, because the settlements vary from insurer to insurer, expire after a certain term, and are geared to the parties that brought them, typically providers.

Healthcare providers have long battled health insurance companies over improperly delayed and denied claims. Recently, however, providers have acted through organizations such as the American Medical Association, suing health insurance companies over their claims processing procedures. The complaints have included claims of improper activities to reduce provider reimbursement, including downcoding ${ }^{233}$ and bundling, ${ }^{234}$ as well as delays and improper

respect to the plan:

[S]olely in the interest of the participants and beneficiaries ... with the care, skill, prudence, and diligence under the circumstances then prevailing that a prudent man acting in like capacity and familiar with such matters would use in the conduct of an enterprise of a like character and with like aims.

29 U.S.C. $\$ 1104(a)(1)$.

231. See supra note 215.

232. The AMA's website sets out eleven different class action settlements and their terms. Health Insurer Settlements, AM. MED. Ass'N, http://www.ama-assn.org/ama/pub/advocacy/currenttopics-advocacy/private-sector-advocacy/health-insurer-settlements.page (last visited Mar. 27, 2011).

233. AM. MED. Ass'N, supra note 20, at 23 ("Downcoding occurs when a health insurer unilaterally reduces the level of complexity of a[] . . service or procedure. . . . Health insurers often base their payment on a lower valued (and lower complexity) . . code instead of the higher valued (and higher complexity) . . . code originally reported for payment.").

234. Id. at 19 ("Bundling occurs when a practice submits a claim for two or more separate, distinct ... procedures and services performed on a patient during a single visit. The health insurer considers the two or more separate, distinct procedures and services as one and reimburses the practice for only one procedure or service performed-often the one with the lowest reimbursement —or reduces payment for the two or more procedures or services."). 
denials. $^{235}$ These lawsuits, notably those consolidated as a Multi-District Litigation lawsuit in Florida, have achieved settlement agreements that include specific, measurable improvements to claims processing procedures. ${ }^{236}$ Settlements have included terms that increase transparency and predictability in claims processing, such as the inclusion of specific, detailed definitions of certain plan terms, ${ }^{237}$ interest payments for claims paid beyond deadlines, prohibitions against specific actions with regard to billing codes, and other terms. ${ }^{238}$

Reform through class action, however, is a poor substitute for broader reform. ${ }^{239}$ First, Participants are not typically parties to these agreements. Plaintiff classes of healthcare providers are certified more readily than classes of Participants, due to the perceived individual facts and lack of uniform defendant actions surrounding the claims. ${ }^{240}$ The settlement agreements therefore carve out special rules that do not include all ERISA stakeholders. When Participants are not class members, the resulting agreements, while beneficial to Participants, are geared to the providers' concerns. ${ }^{24 \mathrm{I}}$ Second, only providers can enforce the agreements' terms; Participants are left out. ${ }^{242}$ Third, the agreements vary from

235. See, e.g., Love v. Blue Cross \& Blue Shield Ass'n, No. 03-21296CIV/MORENO/SIMONTON (S.D. Fla. 2007) (notice of proposed settlement of class action), http://www.bcbsm.com/pdf/lovenotice.pdf ("The Complaint in this Action alleges that . . the Blue Parties, among others, engaged in a conspiracy to improperly deny, delay, and/or reduce payments to physicians.").

236. The Aetna settlement with all U.S. physicians, for example, included a settlement fund of $\$ 100$ million to be paid to physicians, a clear definition of "medical necessity," stricter deadlines for paying claims and the payment of interest on late-paid claims, an independent appeal process for physician disputes, and other terms. Christopher Guadagnino, MDs Weigh HMO Settlements, PHYSICIAN's NEwS Dig. (Sept. 23, 2003), http://www.physiciansnews.com/2003/09/23/mds -weigh-hmo-settlements.

237. Id.

238. Id. (noting that the provider class actions have brought about changes in reimbursement practices that provider groups had previously sought-unsuccessfully-through legislative channels and direct negotiation).

239. Id. (quoting American Medical Association President Donald J. Palmisano as stating that reform through class action is a "last resort" and advocating more fundamental reform).

240. Compare Klay v. Humana, Inc., 382 F.3d 1241 (1 l th Cir. 2004) (affirming certification of provider class alleging systematic underpayment of claims), with In re Managed Care Litig., 209 F.R.D. 678, 686 (S.D. Fla. 2002) (denying putative Participant class's motion for certification due to lack of a uniform scheme directed at plaintiffs).

241. See, e.g., Blue Cross Blue Shield Settlement Information, AM. MEd. Ass'N, http://www.ama-assn.org/ama/pub/advocacy/current-topics-advocacy/private-sector-advocacy/ health-insurer-settlements/blue-cross-blue-shield.page (last visited June 23, 2010) (detailing business practices such as automatic "downcoding" of certain billing codes that would no longer occur under the settlement agreement's terms).

242. See, e.g., Highmark Settlement, HMO SETTLEMENTS.COM, http://www.hmosettlements. 
lawsuit to lawsuit, so that no generally accepted standards emerge. Fourth, the agreements do not result in enduring change because they expire after a certain term of years. ${ }^{243}$

The class action settlement agreements do, however, show that a reform movement is underway, but also that the results at present are uneven. Consistent, inclusive, and effective reform must come from changes to ERISA and its regulations, so that the rules are applicable to all.

\section{CONCLUSION}

When Participants and their advocates press for ERISA reform, employers and health insurance companies often respond that employee benefits are purely voluntary initiatives, and that if the provision of benefits is too onerous, employers may simply decline to provide them. ${ }^{244}$ Even so, employee benefits should not be confused with charity. Employees generally accept benefits in lieu of additional compensation. In turn, employers are able to attract employees by providing benefit packages and are able to receive favorable tax treatment in order to do so. ${ }^{245}$ And employees generally contribute to premium costs as well. ${ }^{246}$ More importantly, however, the voluntary nature of the system does not excuse the provision of illusory or unfair benefits. In any employer calculation of the cost of benefits, employers should take into account that all regulations and rules will be followed carefully.

The need for new remedies for improper processing of healthcare claims is more pressing than ever. More than 177 million Americans receive health care through their employers, ${ }^{247}$ and ERISA plans are now the vehicle for providing the majority of healthcare coverage for those not eligible for Medicare. In addition, increasing numbers of ERISA plans are self-insured, ${ }^{248}$ therefore

com/pages/highmark.html (last visited April 24, 2011) (describing procedures to dispute compliance with settlement terms).

243. Health Insurer Settlements, supra note 232.

244. Conkright v. Frommert, $130 \mathrm{~S}$. Ct., 1640, 1648 (2010) (noting that the provision of employee benefits is purely voluntary); 29 C.F.R. $\S 2560$ (noting the "purely voluntary nature of the system"); HEALTH, EdUC. \& HUM. SERVs. Div., supra note 63, at 16.

245. Mark W. Stanton, Employer-Sponsored Health Insurance: Trends in Cost and Access, U.S. DEP'T. OF HEALTH AND HUM. SERVS., 2 (Sept. 2004), http://www.ahrq.gov/research/empspria/ empspria.pdf.

246. Id.

247. Carmen DeNavas-Walt et al., Income, Poverty, and Health Insurance Coverage in the United States: 2007, U.S. CENSUS BUREAU, 19 (Aug. 2008) http://www.census.gov/prod/2008pubs /p60-235.pdf.

248. Self-insured plans are not considered insurance products and are therefore beyond the reach of many state insurance regulations. Metro. Life Ins. Co. v. Massachusetts, 471 U.S. 724, 746-47 (1985). 
avoiding reform at the state level. ${ }^{249}$ Moreover, benefit denials are now almost always reviewed under the generous abuse-of-discretion standard, and the Supreme Court sees fewer and fewer circumstances in which this standard should be lowered to de novo review. ${ }^{250}$

Whether increased penalties for regulatory violations could be developed by the DOL or by Congress depends on the scope of reform. ERISA gives the DOL authority to "prescribe such regulations as . . . necessary or appropriate to carry out" the statutory provisions securing employee benefit rights. ${ }^{251}$ Thus, targeted, additional regulations to strengthen claims processing could be viewed as securing existing ERISA terms and mandates. If regulatory reform were to broaden significantly the penalties for improper processing so as to change fundamentally the remedies available under ERISA, the regulations might be considered beyond the scope of the DOL's authority such that congressional action would be needed to amend the underlying statute. ${ }^{252}$

The DOL regulations continue to evolve as a result of the PPACA. ${ }^{253}$ As the regulations continue to be refined and strengthened, meaningful enforcement of claims processing procedures should be a priority. The incentives to underpay or deny claims still outweigh any consequence, even with the regulatory reforms resulting from the PPACA. Correct, prompt claims processing should not be left to chance or benevolence-direct, specific penalties should counterbalance the financial pressures on health insurance companies and ensure the provision of benefits as Congress intended.

249. WOOTEN, supra note 11, at 284 (noting the "backlash" against ERISA's lack of remedies and the increase in reform initiatives and noting that these reforms do not reach self-funded plans).

250. Conkright, $130 \mathrm{~S}$. Ct. at 1650 (noting that the creation of ad hoc exceptions to deferential review would cause uniformity problems in plan interpretation).

251. 29 U.S.C. $\S 1135$ (2006); see also $§ 1133$ (plans shall process claims "[i]n accordance with regulations of the Secretary").

252. See Chevron U.S.A. Inc. v. Natural Res. Def. Council, Inc., 467 U.S. 837, 843-44 (1984) ("If Congress has explicitly left a gap for the agency to fill, there is an express delegation of authority to the agency to elucidate a specific provision of the statute by regulation. Such legislative regulations are given controlling weight unless they are arbitrary, capricious, or manifestly contrary to the statute.").

253. Interim Final Rules for Group Health Plans and Health Insurance Issuers Relating to Internal Claims and Appeals and External Review Processes Under the Patient Protection and Affordable Care Act, 75 Fed. Reg. 43,330, 43,332 (July 23, 2010). 